\title{
SOIL AND FRESHWATER NEMATODES OF THE IBERIAN FAUNA: A SYNTHESIS
}

\author{
R. Peña-Santiago*, J. Abolafia, P. Guerrero, G. Liébanas \& M. Peralta
}

\begin{abstract}
The first available compilation of Iberian soil and freshwater nematodes is presented in this paper. The inventory is currently made up of 981 species belonging to 236 genera, 77 families and 12 orders. Data of the Iberian nematode fauna are compared with other components of the Iberian biota, as well as the nematode fauna of other geographical regions. Quantitative and qualitative aspects of the nematode inventory are analyzed and discussed, paying special attention to the kind of information available for each species, and concluding that practically one-third of Iberian species are deficiently characterized and need further study. Endemicity of Iberian species is also considered: 143 species, $14.6 \%$ of the total, are restricted (in their distribution) to the Iberian geography, most of them being members of the orders Dorylaimida (87) and Tylenchida (29), which are also the most diversified nematode taxa. Practical or applied interest of knowledge of the Iberian nematode fauna is commented and supported with examples and recent contributions. Finally, an alphabetical list of the species, ordered by specific name, is provided.
\end{abstract}

Key words: Balearic Islands, Compilation, Endemisms, Faunistics, Freshwater, Iberian Peninsula, Nematoda, Soil.

\section{RESUMEN}

\section{Nematodos edáficos y de agua dulce de la fauna ibérica: una síntesis}

En esta contribución se presenta una recopilación de las especies ibéricas de nematodos de suelo y de agua dulce, la primera de este tipo realizada hasta el momento. El inventario actual lo componen 981 especies de 236 géneros, 77 familias y 12 órdenes. Los datos correspondiente a la fauna ibérica de nematodos se compara con la de otros táxones de la biota ibérica. Se analizan y se discuten distintos aspectos cuantitativos y cualitativos de la fauna nematológica, con especial énfasis en el tipo de información disponible sobre cada especie, y se concluye que casi una tercera parte de las especies ibéricas permanecen insuficientemente caracterizadas, razón por la cual requieren de estudios adicionales. La endemicidad de las especies es así mismo objeto de atención: 143 especies, un 14.6\% del total están restringidas en su distribución al ámbito ibérico, en su mayor parte pertenecientes a los órdenes Dorylaimida (87) y Tylenchida (29), por otra parte los más diversificados de entre los pertenecientes al filo. El interés básico y aplicado del conocimiento de la fauna de nematodos es comentado e ilustrado con aportaciones recientes y ejemplos. Por último, se presenta una lista de todas las especies de la fauna ibérica, ordenadas alfabéticamente por su epíteto específico.

Palabras clave: Agua dulce, Compendio, Endemismos, Faunística, Islas Baleares, Nematodos edáficos, Península Ibérica, Suelo.

* Departamento de Biología Animal, Biología Vegetal y Ecología, Universidad de Jaén. Campus "Las Lagunillas" s/n, Edificio B3, 23071-Jaén, Spain. Email: rpena@ujaen.es 


\section{Introduction}

The biodiversity of any territory is one of its main distinctive features and its characterization serves fundamental and applied purposes. The biota of soil and freshwater sediments has hitherto received little attention, although it plays an important role in their respective food webs. Nematodes (phylum Nematoda or Nemata) are a highly diversified zoological group, which displays a wide trophic spectrum and shows perhaps the widest geographical spread among animals. Moreover, they are a major component of living communities inhabiting soils and freshwater bodies.

Regional continental nematode faunas practically have not been studied, and little information is available on their distribution patterns as well as on processes behind them. Soil and freshwater Iberian nematodes have been recorded throughout the last five decades, starting with the work of Gadea (1952), the pioneering Spanish nematologist. In the following decades, other authors made relevant contributions in the field: Jiménez-Millán and his collaborators (Arias, Bello, Romero) and TobarJiménez from the sixties; Jiménez-Guirado and Palomo from the seventies; de Andrés, Castillo, Hernández, Navas, Nombela, Ocaña and PeñaSantiago in the eighties; and several young nematologists (Abolafia, Armendáriz, Escuer, Galeano, Liébanas, Talavera) in the nineties.

Lately, a series of compendia of soil and freshwater nematodes recorded within the Iberian geographical range have been published. Abolafia \& Peña-Santiago (2001) compiled the species belonging to the order Rhabditida, Peña-Santiago et al. (2003) the order Dorylaimida, Peña-Santiago et al. (2004) the order Tylenchida, and Peña-Santiago et al. (2005) the remaining (minor) orders Enoplida, Triplonchida, Mononchida, Chromadorida, Desmodorida, Monhysterida, Araeolaimida, Plectida and Aphelenchida.

The aim of the present contribution is to update the inventory of Iberian nematode species and provide a general panorama of our current knowledge (of them) as well to discuss its fundamental and applied interest.

\section{Updating the inventory}

This work has been undertaken to compile information recently available in specialized literature, to include new records or those data that were overlooked, and/or to correct some noted errors.
Twenty nine (six dorylaimid, 21 rhabditid, two tylenchid and one triplonchid) species were added to the Iberian Fauna catalogue (Appendix 1), as well as many new records of other species previously reported [see also Díez-Rojo et al. (2006) for a compilation of plant-parasitic species recorded in Castilla y León region]. Nine (one dorylaimid, seven rhabditid and one triplonchid) species are tentatively considered to be Iberian endemisms since their current distribution is restricted to peninsular Spain and Portugal.

The new information is presented below, following a general scheme identical to that used in previous compendia.

\section{Order DORYLAIMIDA}

abrantinum, Xiphinema Roca \& Pereira, 1991

NEW RECORDS: Guadiamar river basin/Sevilla (MurilloNavarro et al., 2005).

aceri, Xiphinema Chizhov, Kiev \& Turkina, 1986

NEW RECORDS: Several localities in the Iberian Peninsula (Arias et al., 2005); Guadiamar river basin/Sevilla (Murillo-Navarro et al., 2005).

REMARKS: Arias et al. (2005) provided description, illustrations and measurements of Iberian populations of this species.

africanus, Longidorus Merny, 1966

Distribution: Herdade do Carvalhal/Ribatejo/Portugal (Bravo \& Roca, 1995).

REMARKS: Bravo \& Roca (1995) provided description, illustrations and measurements of Portuguese populations of this species.

amylovorus, Aporcelaimellus (Thorne \& Swanger, 1936) Heyns, 1965

NEW RECORDS: Guadiamar river basin/Sevilla (PeñaSantiago et al., 2005).

andrassyi, Allodorylaimus (Meyl, 1955) Andrássy, 1986

REMARKS: Erroneously named Eudorylaimus andrassyi by Peña-Santiago et al. (2003).

bastiani, Mesodorylaimus (Bütschli, 1873) Andrássy, 1959

NEW RECORDS: Guadiamar river basin/Sevilla (PeñaSantiago et al., 2005). 
belmontense, Xiphinema Roca \& Pereira, 1992

NEW RECORDS: Guadiamar river basin/Sevilla (MurilloNavarro et al., 2005).

brevicaudatus, Mesodorylaimus Abolafia \& PeñaSantiago, 1996

NEW RECORDS: Guadiamar river basin/Sevilla (PeñaSantiago et al., 2005).

bulbiferus, Discolaimoidess (Cobb, 1906) Heyns, 1963

NEW RECORDS: Guadiamar river basin/Sevilla (PeñaSantiago et al., 2005).

declinatoaculeatus, Epacrolaimus (Kreis, 1924) Andrássy, 2000

Synonymy: Aporcelaimus vorax Thorne \& Swanger, 1936

NEW RECORDS: Several localities from southeastern Iberian Peninsula (Martínez-Olías et al., 2005).

REMARKS: Martínez-Olías et al. (2005) provided description, measurements and illustrations, including SEM photographs of Andalusian populations. This species was recorded as Aporcelaimus vorax by PeñaSantiago et al. (2003).

diversicaudatum, Xiphinema (Micoletzky, 1927) Thorne, 1939

NEW RECORDS: Guadiamar river basin/Sevilla (MurilloNavarro et al., 2005).

engadinensis, Pungentus (Altherr, 1950) Altherr, 1952

NEW RECORDS: Guadiamar river basin/Sevilla (PeñaSantiago et al., 2005).

eurydorys, Aporcelaimus (Ditlevsen, 1911) Thorne \& Swanger, 1936

NEW RECORDS: Erroneously named A. eurydoris by Peña-Santiago et al. (2003).

gersoni, Xiphinema Roca \& Bravo, 1993

NEW RECORDS: Guadiamar river basin/Sevilla (MurilloNavarro et al., 2005).

heterurus, Lindseyus (Schuurmans-Stekhoven \& Teunissen, 1938) Coomans \& Kheiri, 1986

NEW RECORDS: Several localities in peninsular Spain (Jiménez-Guirado \& Murillo-Navarro, 2004).

ibericus, Mesodorylaimus Abolafia \& Peña-Santiago, 1997

NEW RECORDS: Guadiamar river basin/Sevilla (PeñaSantiago et al., 2005). index, Xiphinema Thorne \& Allen, 1950

NEW RECORDS: Guadiamar river basin/Sevilla (MurilloNavarro et al., 2005).

lupini, Xiphinema Roca \& Pereira, 1993

NEW RECORDS: Guadiamar river basin/Sevilla (MurilloNavarro et al., 2005).

monohystera, Ecumenicus (De Man, 1880) Thorne, 1974

NEW RECORDS: Guadiamar river basin/Sevilla (PeñaSantiago et al., 2005).

obtusicaudatus, Aporcelaimellus (Bastian, 1865) Altherr, 1968

NEW RECORDS: Guadiamar river basin/Sevilla (PeñaSantiago et al., 2005).

pachtaicum, Xiphinema (Tulaganov, 1938) Kirjanova, 1936

SYNONYMY: Xiphinema mediterraneum Martelli \& Lamberti, 1967.

NEW RECORDS: Santa Olalla/Toledo (Nombela et al., 1998); Guadiamar river basin/Sevilla (MurilloNavarro et al., 2005; Peña-Santiago et al., 2005).

REMARKS: Peña-Santiago et al. (2003) recorded X. pachtaicum and $X$. mediterraneum as separate and different species.

parasiticus, Dorylaimus Navarro, Guerrero, PérezMellado \& Lluch, 1995

Distribution: Santuario de la Chilla/Ávila (Navarro et al., 1995).

REMARKS: Navarro et al. (1995) originally described this species that might be an Iberian endemism. The species was collected from body cavities (intestine, stomach and general body cavity) of several amphibian species, a remarkable novelty since it is the first report of a dorylaim found parasityzing (?) an animal species.

popus, Dorylaimus Gagarin, 1981

Distribution: Cigüela river/Toledo (Jiménez-Guirado \& Murillo-Navarro, 2001).

REMARKS: Jiménez-Guirado \& Murillo-Navarro (2001) provided description, measurements and illustrations, including photographs of one Iberian population.

profundorum, Longidorus Hooper, 1965

NEW RECORDS: Santa Olalla/Toledo (Nombela et al., 1998). 
pyrenaicum, Xiphinema Dalmasso, 1969

NEW RECORDS: Several localities in Iberian Peninsula (Arias et al., 2005); Guadiamar river basin/Sevilla (Murillo-Navarro et al., 2005).

REMARKS: Arias et al. (2005) provided description, illustrations and measurements of Iberian populations of this species.

rivesi, Xiphinema Dalmasso, 1969

NEW RECORDS: Madrid province (Arias \& Navacerrada, 1973); several localities in southern Iberian Peninsula (Arias et al., 1991); Montseny Mountains/Barcelona (Escuer, 1995); several localities/Ciudad Real and Toledo (Bello et al., 2004). See also Bello et al. (2005) for a review.

REMARKS: Bello et al. (2005) provided a detailed re-evaluation of geographical distribution in Spain of this quarantine species.

setariae, Xiphinema Luc, 1958

SYNONYMY: Xiphinema vulgare Tarjan, 1964.

REMARKS: Recorded as $X$. vulgare by Peña-Santiago et al. (2003).

silvesi, Xiphinema Roca \& Bravo, 1998

NEW RECORDS: Guadiamar river basin/Sevilla (MurilloNavarro et al., 2005).

sublabiatus, Metaporcelaimus (Thorne \& Swanger, 1936) Andrássy, 2000

REMARKS: Recorded as Aporcelaimus sublabiatus by Peña-Santiago et al. (2003).

tenuis, Discolaimoides (Furstenberg \& Heyns, 1965) Das, Khan \& Loof, 1969

NEW RECORDS: Guadiamar river basin/Sevilla (PeñaSantiago et al., 2005; as Discolaimoides cf. tenuis).

vinearum, Longidorus Bravo \& Roca, 1995

Distribution: Two localities/Lisboa/Portugal (Bravo \& Roca, 1995).

REMARKS: Bravo \& Roca (1995) originally described this species that may be an Iberian endemism.

\section{Order RHABDITIDA}

andalusicus, Acrobeles Abolafia \& Peña-Santiago, 2004

Distribution: Escúllar/Almería and Sierra de Huétor/Granada (Abolafia \& Peña-Santiago, 2004).
Remarks: Abolafia \& Peña-Santiago (2004) originally described this species that may be an Iberian endemism.

arenicola, Acrobeloides Abolafia \& Peña-Santiago, 2003

Distribution: Cabo de Gata and Tabernas Desert/ Almería (Abolafia \& Peña-Santiago, 2003a)

REMARKs: Abolafia \& Peña-Santiago (2003a) originally described this species that may be an Iberian endemism.

bodenheimeri, Acrobeloides (Steiner, 1936) Thorne, 1937

Synonymy: Acrobeles bodenheimeri Steiner, 1936; Cephalobus bodenheimeri (Steiner, 1936) Andrássy, 1984; Rafiqius bodenheimeri (Steiner, 1936) Khan \& Hussain, 1997; Acrobeloides rotundifolius Bussau, 1991.

Distribution: Several localities in southern Iberian Peninsula (Abolafia \& Peña-Santiago, 2003a).

REMARKs: Abolafia \& Peña-Santiago (2003a) provided description, illustrations and measurements of Iberian populations of this species.

cylindricus, Acrobeles Ivanova, 1968

Distribution: Sierra de Almijara/Málaga (Abolafia \& Peña-Santiago, 2004).

Remarks: Abolafia \& Peña-Santiago (2004) provided description, illustrations and measurements of Iberian populations of this species.

demani, Chiloplacus (Thorne, 1925) Thorne, 1937

Synonymy: Acrobeles demani Thorne, 1925; Acrobeles incurvus Thorne, 1925; Chiloplacus incurvus (Thorne, 1925) Thorne, 1937

Distribution: Several localities in southeastern Iberian Peninsula (Abolafia \& Peña-Santiago, 2003b).

REMARKS: Abolafia \& Peña-Santiago (2003b) provided description, illustrations and measurements of Iberian populations of this species.

elongatus, Pseudacrobeles (Pseudacrobeles) (de Man, 1880) Abolafia \& Peña-Santiago, 2005

NEW RECORDS: Several localities in peninsular Spain (Abolafia \& Peña-Santiago, 2005).

Remarks: Abolafia \& Peña-Santiago (2005) provided description, illustrations and measurements of Iberian populations of this species. This species was previously reported (see Abolafia \& Peña-Santiago, 2001) as Heterocephalobus elongatus.

eurystoma, Pseudacrobeles (Pseudacrobeles) (Andrássy, 1967) Abolafia, Liébanas \& Peña-Santiago, 2002

Synonymy: Heterocephalobus eurystoma Andrássy, 1967. 
Distribution: Cazorla, Segura and Las Villas Mountains Natural Park/Jaén, and La Sagra/Granada (Abolafia et al., 2002).

REMARKS: Abolafia et al. (2002) provided description, illustrations and measurements of Iberian populations of this species.

\section{hamatus, Cervidellus Thorne, 1937}

Distribution: Sierra Mágina/Jaén, Sierra de los Filabres/Almería, Sierra de Guillimona/Granada, Los Bermejales Dam/Granada (Abolafia et al., 2003).

REMARKS: Abolafia et al. (2003) provided description, illustrations and measurements of Iberian populations of this species.

hooperi, Eucephalobus Marinari-Palmisano, 1967

Distribution: Three localities/Málaga and Santa Fé/Granada (Abolafia \& Peña-Santiago, 2002).

REMARKS: Abolafia \& Peña-Santiago (2002) provided description, illustrations and measurements of Iberian populations of this species.

lanceolatus, Nothacrobeles Abolafia \& Peña-Santiago, 2003

Distribution: Cabo de Gata/Almería, Sierra de Almijara/Granada (Abolafia and Peña-Santiago, 2003c).

REMARKS: Abolafia \& Peña-Santiago (2003c) originally described this species that may be an Iberian endemism.

lunensis, Nothacrobeles Shahina \& De Ley, 1997

Distribution: Sierra de Huétor/Granada (Abolafia \& Peña-Santiago, 2003c; as Nothacrobeles cf. lunensis).

REMARKS: Abolafia \& Peña-Santiago (2003c) provided description, illustrations and measurements of Iberian populations of this species.

maginensis, Chiloplacus Abolafia \& Peña-Santiago, 2003

Distribution: Sierra Mágina/Jaén (Abolafia \& PeñaSantiago, 2003b).

REMARKS: Abolafia \& Peña-Santiago (2003b) originally described this species that may be an Iberian endemism.

magnus, Chiloplacus Rashid \& Heyns, 1990

Distribution: Salinas de Cabo de Gata/Almería (Abolafia and Peña-Santiago, 2003b).

REMARKS: Abolafia \& Peña-Santiago (2003b) provided description, illustrations and measurements of Iberian populations of this species. punctata, Zeldia (Thorne, 1925) Thorne, 1937

SynONymy: Acrobeles punctatus Thorne, 1925; Acrobeles glaphyrus Steiner, 1935; Zeldia glaphyra (Steiner, 1935) Thorne, 1937; Zeldia serrata Heyns, 1962; Zeldia paucipunctata Andrássy, 1967; Zeldia minor Allen et Noffinger, 1972.

Distribution: Sierras de Andújar/Jaén and Salinas de Cabo de Gata/Almería (Abolafia \& Peña-Santiago, 2003c).

Remarks: Abolafia \& Peña-Santiago (2003c) provided description, illustrations and measurements of Iberian populations of this species.

pygmaea, Stegelletina Abolafia \& Peña-Santiago, 2003

Distribution: Tabernas/Almería (Abolafia \& PeñaSantiago, 2003d).

REMARKs: Abolafia \& Peña-Santiago (2003d) originally described this species that may be an Iberian endemism.

salinaria, Stegelletina Abolafia \& Peña-Santiago, 2003

Distribution: Salinas de Cabo de Gata/Almería (Abolafia \& Peña-Santiago, 2003d).

REMARKs: Abolafia \& Peña-Santiago (2003d) originally described this species that may be an Iberian endemism.

setosus, Acrobeloides Brzeski, 1962

Distribution: Carchuna/Granada, Morrón de los Genoveses/Almería, and Desfiladero de los Gaitanes/ Málaga (Abolafia \& Peña-Santiago, 2003a).

REMARKs: Abolafia \& Peña-Santiago (2003a) provided description, illustrations and measurements of Iberian populations of this species.

tabacum, Pseudacrobeles (Pseudacrobeles) (Rashid, Geraert \& Sharma, 1985) De Ley, Siddiqi \& Boström, 1993

DistriBUtion: Huelma/Jaén (Abolafia et al., 2005).

REMARKS: No additional information of taxonomical interest about this species is available.

tenuis, Chiloplacus Rashid et Heyns, 1990

Distribution: Several localities in southeastern Iberian Peninsula (Abolafia \& Peña-Santiago, 2003b).

Remarks: Abolafia \& Peña-Santiago (2003b) provided description, illustrations and measurements of Iberian populations of this species.

trilineatus, Chiloplacus Steiner, 1940

DistRIBUTION: Several localities in southeastern Iberian Peninsula (Abolafia \& Peña-Santiago, 2003b). 
REMARKS: Abolafia \& Peña-Santiago (2003b) provided description, illustrations and measurements of Iberian populations of this species.

unguicolis, Pseudacrobeles (Pseudacrobeles) Abolafia, Liébanas \& Peña-Santiago, 2002

Distribution: Several localities in southeastern Iberian Peninsula (Abolafia et al., 2002).

REMARKS: Abolafia et al., (2002) originally described this species that may be an Iberian endemism.

variabilis, Pseudacrobeles (Pseudacrobeles) (Steiner, 1936) Steiner, 1938

SynONymy: Acrobeles variabilis Steiner, 1936; Acrobeloides variabilis (Steiner, 1936) Goodey, 1951

DistriBution: Salinas de Cabo de Gata/Almería (Abolafia et al., 2002).

REMARKS: Abolafia et al. (2002) provided description, illustrations and measurements of Iberian populations of this species.

\section{Order TRIPLONCHIDA}

divergens, Paratrichodorus Almeida, Santos, Abrantes \& Decraemer, 2005

Distribution: Braga/Portugal (Almeida et al., 2005).

REMARKS: Almeida et al. (2005) originally described this species that may be an Iberian endemism.

hispanus, Paratrichodorus Roca \& Arias, 1986

NEW RECORDS: Several localities/Portugal (Almeida et al., 2005).

REMARKS: Almeida et al. (2005) provided measurements and illustrations, including SEM pictures of Portuguese populations of this species.

\section{Order TYLENCHIDA}

arenaria, Meloidogyne (Neal, 1889) Chitwood, 1949

NEW RECORDS: Several localities/Portugal (Pais \& Abrantes, 1989); several localities in peninsular Spain (Flores-Romero \& Navas, 2005).

REMARKS: Pais \& Abrantes (1989) and Flores-Romero \& Navas (2005) studied the molecular diversity of Iberian populations.

artiella, Meloidogyne Franklin, 1961

NEW RECORDS: Alhama de Granada/Granada and Fuentesauco/Zamora (Hernández-Fernández et al., 2005). clavicaudata, Boleodorus (Thorne, 1941) Ebsary, 1991

Synonymy: Basiria clavicaudatus Thorne, 1941.

REMARKS: Peña-Santiago et al. (2004) erroneously included Boleodorus clavicaudatus Thorne, 1941 as a synonym of the same species, the correct synonym being Basiria clavicaudatus Thorne, 1941.

dipsaci, Ditylenchus (Kühn, 1857) Filipjev, 1936

REMARKS: Bello et al. (2005) provided a detailed re-evaluation of the geographical distribution in Spain of this quarantine species.

graminis, Anguina (Hardy, 1850) Filipjev, 1936

SYNONYMY: Vibrio graminis Hardy, 1850; Tylenchus graminis (Hardy, 1850) Marcinowski, 1909; Anguillulina graminis (Hardy, 1850) Goodey, 1932.

Distribution: San Rafael/Segovia (Cogolludo, 1925; Jiménez-Millán et al., 1965).

REMARKS: No information of taxonomic interest about Iberian populations of this species is available.

hapla, Meloidogyne Chitwood, 1949

NEW RECORDS: Several localities/Portugal (Pais \& Abrantes, 1989).

REMARKS: Pais \& Abrantes (1989) studied the molecular diversity of Iberian populations.

hispanica, Meloidogyne Hirschmann, 1986

NEW RECORDS: Several localities/Portugal (Pais \& Abrantes, 1989

REMARKS: Pais \& Abrantes (1989) studied the molecular diversity of Iberian populations.

incognita, Meloidogyne (Kofoid \& White, 1919) Chitwood, 1949

New ReCords: Several localities/Portugal (Pais \& Abrantes, 1989); several localities in peninsular Spain (Flores-Romero \& Navas, 2005).

REMARKS: Pais \& Abrantes (1989) and Flores-Romero \& Navas (2005) studied the molecular diversity of Iberian populations.

javanica, Meloidogyne (Treub, 1889) Chitwood, 1949

NEW RECORDS: Several localities/Portugal (Pais \& Abrantes, 1989); several localities in peninsular Spain (Flores-Romero \& Navas, 2005).

REMARKS: Pais \& Abrantes (1989) \& Flores-Romero and Navas (2005) studied the molecular diversity of Iberian populations. 
lusitanica, Melodiogyne Abrantes \& Santos, 1992

New RECORDS: Cadaixo/Miranda do Corvo/Portugal (Abrantes et al., 1992).

minutus, Paratylenchus Linford, 1949

REMARKS: Erroneously named Pratylenchus minutus by Peña-Santiago et al. (2004).

murrayi, Ogma Southern, 1914

SYNONYMY: Hoplolaimus murrayi (Southern, 1914) Menzel, 1917; Iota murrayi (Southern, 1914) Micoletzky, 1925; Criconema murrayi (Southern, 1914) Taylor, 1936; Varisquamata murrayi (Southern, 1914) Khan, Chawla \& Saha, 1976.

Distribution: Fuenteguinaldo/Salamanca (Escuer et al., 1999).

REMARKS: No information of taxonomic interest about Iberian populations of this species is available.

pallida, Globodera (Stone, 1973) Behrens, 1975

REMARKS: Bello et al. (2005) provided a detailed re-evaluation of the geographical distribution in Spain of this quarantine species.

rostochiensis, Globodera (Wollenweber, 1923) Skarbilovich, 1959

REMARKS: Bello et al. (2005) provided a detailed re-evaluation of the geographical distribution in Spain of this quarantine species.

semipenetrans, Tylenchulus Cobb, 1931

NEW RECORDS: Several localities in northeastern Iberian Peninsula (Gene et al., 2005).

zeae, Heterodera Koshy, Swarup \& Sethi, 1971

New RECORDS: Several localities in Portugal (Correia \& Abrantes, 2005).

REMARKS: Correia \& Abrantes (2005) provided description, measurements and illustrations, including SEM pictures, of Portuguese populations of this species.

\section{Characterizing the nematode Iberian fauna}

\section{HOW MANY SPECIES?}

Table 1 summarizes data from previous compendia on nematode Iberian fauna as well as the new records provided here, representing the 'state of the art' at the end of 2005. According to this updated information, 981 (soil and freshwater) nematode species belonging to 236 genera and 77 families have hitherto been reported from the Iberian geography. Two major orders, Dorylaimida and Tylenchida, each make up almost one-third of the Iberian fauna, having more than 60 genera and 300 species. Rhabditida is a medium sized order, with 40 genera and 100 species; and the rest are minor orders, being represented by less than 20 genera and less than 50 species.

Although these figures should be taken with caution (see below), they are interesting per se for comparative purposes. For instance, the number of nematode species is about one-sixth that of vascular plants (5597; see Smythies, 1984-1986; Castroviejo, 2002), one-fourth of butterflies (4243; see Vives-Moreno, 1994; Ortuño, 2002), and very close to the number of vertebrates (1068; see Ramos et al., 2002).

Unfortunately, available information for other territories or regions is very poor, and no detailed comparative study can be carried out.

Table 2 provides a compilation of available data from Europe (Bongers, 2006), the Netherlands (Bongers, 1988) and Hungary (Andrássy, 2005). Bongers (2006) has inventoried 115 families, 483 genera and 2952 nematode species in the 'Fauna Europea' project. Thus, Iberian nematodes currently represent about two-thirds $(67 \%)$, one half $(52 \%)$ and one-third $(33 \%)$, respectively, of the total European fauna. On the other hand, the number of Iberian species is higher than those found in the Netherlands (635) and Hungary (720), two countries whose extension is less than that of the Iberian region but which have a longer tradition of nematological studies.

\section{QUALITY OF AVAILABLE INFORMATION}

Appendix 2 provides the complete list of Iberian species ordered by specific epithet, with indication of the order to which they belong. Nevertheless, data from both Table 1 and Appendix 2 should be taken and managed with some caution because the quality of information varies depending on the taxon considered. We have (tentatively) classified/divided Iberian species into four groups on the base of type of data available about them.

(1) Species whose presence in Iberian soils or freshwater bodies needs to be confirmed: only occasional (generally old) records are known, usually obtained as results of general surveys other than monographic studies on particular taxa; identification presents serious doubts (for 
Table 1.- Quantitative information on Iberian (soil and freshwater) nematode taxa, with special reference to (tentative) endemic species (Percentages in brackets).

Tabla 1.- Información cuantitativa sobre las taxones ibéricos de nematodos (edáficos y de agua dulce), con especial referencia (tentative) a las especies endémicas (porcentaje entre paréntesis).

\begin{tabular}{|c|c|c|c|c|c|}
\hline $\begin{array}{ll}N^{0} \text { taxa } \\
\text { Order }\end{array}$ & Families & Genera & Species & Endemic species $^{1}$ & Endemicity (\%) \\
\hline Aphelenchida & $5(6.5)$ & $8(3.4)$ & $33(3.4)$ & $0(0.0)$ & 0.0 \\
\hline Araeolaimida & $1(1.3)$ & $1(0.4)$ & $3(0.3)$ & $0(0.0)$ & 0.0 \\
\hline Chromadorida & $4(5.2)$ & $5(2.1)$ & $11(1.1)$ & $1(0.7)$ & 9.1 \\
\hline Desmodorida & $1(1.3)$ & $1(0.4)$ & $6(0.6)$ & $2(1.4)$ & 33.3 \\
\hline Dorylaimida & $14(18.2)$ & $65(27.5)$ & $318(32.4)$ & $87(60.8)$ & 27.4 \\
\hline Enoplida & $3(3.9)$ & $6(2.5)$ & $21(2.1)$ & $0(0.0)$ & 0.0 \\
\hline Monhysterida & $2(2.6)$ & $6(2.5)$ & $28(2.9)$ & $2(1.4)$ & 7.1 \\
\hline Mononchida & $4(5.2)$ & $8(3.4)$ & $31(3.2)$ & $4(2.8)$ & 12.9 \\
\hline Plectida & $8(10.4)$ & $13(5.5)$ & $44(4.5)$ & $4(2.8)$ & 9.1 \\
\hline Rhabditida & $12(15.6)$ & $40(16.9)$ & $100(10.2)$ & $8(5.6)$ & 8.0 \\
\hline Triplonchida & $6(7.8)$ & $16(6.8)$ & $48(4.9)$ & $6(4.2)$ & 12.5 \\
\hline Tylenchida & $17(22.1)$ & $67(28.4)$ & $338(34.4)$ & $29(20.3)$ & 8.6 \\
\hline Total & 77 & 236 & 981 & 143 & 14.6 \\
\hline
\end{tabular}

${ }^{1}$ Tentative or provisional (see the text).

${ }^{2}$ Referred to species.

instance, Helicotylenchus cf. rohtangus) and/or the species in question is more typical of other biogeographical regions.

(2) Species which have been studied under a taxonomical point of view (often with available description, measurements, etc.) but whose information does not fit that previously known for the same species, and/or that were identified many years ago, and have not been found later.

(3) Cosmopolitan or widely distributed species which have never been studied under a taxonomical point of view, but whose presence in the Iberian geography is confirmed because they have been reported repeatedly, and/or identified in monographic studies although information concerning their morphology and morphometry was never published. This is the case of a good number of Xiphinema species.

(4) Confirmed and well characterized Iberian species, whose populations were the object of specialized published papers or monographies, and whose identification does not present reasonable doubts. This occurs with species of the genera Dorylaimoides, Tylencholaimellus, Amplimerlinius, many criconematids, etc.
The corresponding status of every species is indicated (see figures between brackets) in Appendix 2, while Table 3 summarizes information concerning each nematode order. Hardly more than half of Iberian nematode species $(508,51.8 \%)$ are well studied and characterized, and practically onethird $(262+57,32.5 \%)$ of the total needs additional information. The situation, however, is not identical in all taxa. Three (minor) orders, Chromadorida, Mononchida or Plectida, are known best, with their average being quite higher than 3.0; most orders display values within the range $2.5-3.0$, and this means that their status is not satisfactory; only the order Enoplida shows a very deficient panorama, although it is a minor order in number of species. In conclusion, it is evident that additional studies are needed and should be undertaken to complete our knowledge of these taxa.

\section{LEVEL OF ENDEMICITY}

Table 1 shows the number of soil and freshwater nematode endemisms currently registered in the Iberian inventory. The corresponding species are marked with an asterisk (between brackets) in 
Table 2.- Data on the Iberian nematode fauna compared to those from Europe, Hungary and the Netherlands.

Tabla 2.- Táxones de la fauna de nematodos ibéricos comparados con los de Europe, Hungría y Holanda.

\begin{tabular}{|c|c|c|c|c|c|c|c|c|}
\hline \multirow{2}{*}{$\begin{array}{r}\text { Taxa } \\
\text { Region }^{1}\end{array}$} & \multicolumn{2}{|c|}{ Families } & \multicolumn{2}{|c|}{ Genera } & \multicolumn{4}{|c|}{ Species } \\
\hline & $\mathbf{I b}^{5}$ & $\mathbf{E} \mathbf{u}^{2}$ & $\mathrm{Ib}^{5}$ & $\mathbf{E u ^ { 2 }}$ & $I b^{5}$ & $\mathbf{E \mathbf { u } ^ { 2 }}$ & $\mathrm{Ne}^{3}$ & $\mathbf{H u}^{4}$ \\
\hline Order & & & & & & & & \\
\hline Aphelenchida & $5(71)$ & 7 & $8(53)$ & 15 & $33(23)$ & 146 & 26 & 25 \\
\hline Araeolaimida & $1(50)$ & 2 & $1(20)$ & 5 & $3(15)$ & 20 & & 5 \\
\hline Chromadorida & $4(67)$ & 6 & $5(50)$ & 10 & $11(34)$ & 32 & 17 & 14 \\
\hline Desmodorida & $1(50)$ & 2 & $1(50)$ & 2 & $6(50)$ & 12 & - & 4 \\
\hline Desmoscolescida & $0(0)$ & 1 & $0(0)$ & 2 & $0(0)$ & 9 & & 0 \\
\hline Dorylaimida & $14(93)$ & 15 & $65(62)$ & 105 & $318(41)$ & 767 & 141 & 186 \\
\hline Enoplida & $3(60)$ & 5 & $6(55)$ & 11 & $21(14)$ & 154 & 37 & 63 \\
\hline Monhysterida & $2(50)$ & 4 & $6(46)$ & 13 & $28(35)$ & 81 & 21 & 25 \\
\hline Mononchida & $4(100)$ & 4 & $8(44)$ & 18 & $31(29)$ & 108 & 18 & 38 \\
\hline Plectida & $8(89)$ & 9 & $13(52)$ & 25 & $44(38)$ & 116 & 46 & 56 \\
\hline Rhabditida & $12(41)$ & 29 & $40(37)$ & 107 & $100(17)$ & 585 & 106 & 155 \\
\hline Triplonchida & $6(100)$ & 6 & $16(84)$ & 19 & $48(38)$ & 125 & & 9 \\
\hline Tylenchida & $17(68)$ & 25 & $67(55)$ & 122 & $338(42)$ & 797 & 211 & 140 \\
\hline Total & $77(67)$ & 115 & $236(52)$ & 454 & $981(33)$ & 2952 & 635 & 720 \\
\hline
\end{tabular}

${ }^{1}$ Key: Ib-Iberian, Eu-Europe, Ne-the Netherlands, Hu-Hungary.

Data from Bongers (2006).

Data from Bongers (1998)

${ }^{4}$ Data from Andrássy (2005).

${ }^{5}$ In brackets the corresponding percentage respect European fauna

Appendix 2. It has been mentioned above that the inventory is tentative or provisional, and this is particularly so concerning endemisms. At least two principal causes contribute to this provisionality. On the one hand, the nematode fauna of the Mediterranean region has not been studied in detail yet -perhaps with the exception of Italy (including its peninsular territory and some of the islands, for instance Sicily)- and it is very likely that at least part of the Iberian endemisms might be recorded in other geographical areas, a fact that should entail a decrease in the number of Iberian endemic species. On the other hand, the highest number of endemisms appears in the most important (diversified) nematode orders, mainly dorylaims (order Dorylaimida) and tylenchs (order Tylenchida), which are those that have received more attention, that is, there is a logical correlation between sampling and/or 'faunistic' effort and results obtained. In this sense, we must take into account that the Iberian territory has not been covered regularly with general surveys, and that new taxa will be recorded and/or described in the future, some of them certainly new Iberian endemisms.

No study has been published up to now concerning endemic soil and freshwater nematodes from other natural regions, and this makes it impossible to analyze the case of the Iberian Peninsula from a comparative point of view.

\section{APPLIED ASPECTS OF THE IBERIAN NEMATODE FAUNA}

Soil and freshwater nematodes have been studied in the Iberian region not only for basic or fundamental purposes but also to accomplish practical or applied aims. Free-living forms are dominant in both natural and cultivated terrestrial areas and, of course, in freshwater bodies, and the faunistic composition of their respective taxocoenoses is useful to assess the 'health' of the corresponding habitat. But plant parasitic? species are also frequent, and particularly important in agroecosystems where they may cause severe damages. 
Table 3.- Number of Iberian nematode species with an evaluation of the quality of information available about them.

Tabla 3.- Número de species de nematodos ibéricos con estimación de la calidad de la información disponible sobre ellos.

\begin{tabular}{lcccccc}
\hline \multicolumn{1}{c}{ Status $^{\mathbf{1}}$} & & $\mathbf{1}$ & $\mathbf{2}$ & $\mathbf{3}$ & $\mathbf{4}$ & Average \\
Order & $\mathbf{n}^{\mathbf{2}}$ & & & & & \\
\hline Enoplida & 21 & 12 & 1 & 3 & 5 & 2.05 \\
Triplonchida & 48 & 9 & 3 & 11 & 25 & 3.08 \\
Dorylaimida & 318 & 87 & 22 & 29 & 180 & 3.95 \\
Mononchida & 31 & 3 & 2 & 6 & 20 & 3.55 \\
Chromadorida & 11 & 0 & 2 & 1 & 8 & 2.83 \\
Desmodorida & 6 & 2 & 0 & 1 & 3 & 3.00 \\
Monhysterida & 28 & 8 & 1 & 2 & 17 & 2.67 \\
Araeolaimida & 3 & 1 & 0 & 1 & 1 & 3.34 \\
Plectida & 44 & 7 & 3 & 2 & 32 & 2.63 \\
Rhabditida & 100 & 34 & 13 & 9 & 44 & 2.91 \\
Tylenchida & 338 & 90 & 7 & 84 & 157 & 2.85 \\
Aphelenchida & 33 & 9 & 3 & 5 & 16 & $\mathbf{2 . 9 3}$ \\
\hline \multicolumn{1}{c}{ Total } & $\mathbf{9 8 1}$ & $\mathbf{2 6 2}$ & $\mathbf{5 7}$ & $\mathbf{1 5 4}$ & $\mathbf{5 0 8}$ & \\
\hline
\end{tabular}

'A value $(1,2,3,4)$ is assigned to each species depending of information available about it. See the text for additional explanation.

${ }^{2}$ Total number of species per each nematode order.

\section{FREE-LIVING FORMS AND THEIR INTEREST}

Iberian nematode species have been used to test and monitorize the quality of both soil and freshwater habitats. Ocaña \& Picazo (1991) studied the response of the nematode community to organic pollution in the Monachil river (Granada), and found significant correlations between among species distribution and a series of physico-chemical parameters, concluding that a group of species are indicators of organic water pollution.

Members of the orders Dorylaimida and Mononchida -two of the best known Iberian nematode taxa- have been used to evaluate the impact of the perturbation caused by the mining accident occurred in the Guadiamar river basin (Seville) in 1998 and to monitorize the re-colonization process (Peña-Santiago et al., 2003, 2005) in the soils of this area. Two well defined patterns, one spatial and another temporal, were identified, and the interest of these nematode orders as useful bioindicators was corroborated.

\section{Plant PARASITES}

Many nematode species feed on vascular plants, producing a variable range of damages.
Among the members of the order Aphelenchida reported from the Iberian Peninsula, fourteen species of the genus Bursaphelenchus, including the pine wilt desease nematode (B. xylophilus), have been reported from the Iberian peninsula (Arias et al., 2004; Penas et al., 2004) in association with pine and other conifer forests. There are also eleven species of the genus Aphelenchoides, some of them showing pathogenicity on several crops such as rice, ornamental plants and strawberry (Escuer \& Bello, 2000).

The order Tylenchida provides the highest number of plant parasitic neamatodes. The genus Meloidogyne (root-knot nematodes), one of the most damaging agricultural pests, is represented in the Iberian fauna by eleven species, three of which (M. arenaria, M. javanica and $M$. incognita) are particularly ubiquitous and exhibit an extreme polyphagy (Flores-Romero \& Navas, 2005). Thirteen Heterodera species (cyst nematodes) have been recorded from Iberian soils, mainly in association with cereals and pulses (Romero et al., 1973). Also thirteen species of root lesion nematodes of the genus Pratylenchus have been found parasitizing a wide range of host plants, $P$. penetrans, $P$. pratensis, $P$. vulnus and $P$. thornei being among the most fre- 
quent taxa in our cultures. Other important plant parasitic genera such as Helicotylenchus (spiral nematodes), Macroposthonia (ring nematodes) and Paratylenchus (pin nematodes) are well diversified in the Iberian geography, each one with more than 20 species.

The dorylaimid family Longidoridae is very highly diversified in the Iberian region (see Arias, 1979), with 81 species belonging to three genera: Longidorus (20 spp.), Paralongidorus (3 spp.) and Xiphinema (58 spp.). Longidorid nematodes are ectoparasites, and some species are able to transmit plant viruses. Among the 18 longidorid species considered by Taylor \& Brown (1997) to be virus vectors, there seven species reported from the Iberian geography: Longidorus attenuatus, L. elongatus, L. macrosoma, Xiphinema diversicaudatum, $X$. index, $X$. italiae and $X$. rivesi.

Finally, the order Triplonchida is represented with 15 species (López-Pérez et al., 2001) in two genera: Paratrichodorus (6 spp.) and Trichodorus (9 spp.). Like longidorids, trichodorid nematodes are ectoparasites and, in some cases, virus vectors; in fact, Decraemer (1995) has provided a list of trichodorid species which are certainly virus vectors, and eight out of the 15 Iberian species (four Paratrichodorus and four Trichodorus species) are included in this list.

\section{QUARANTINE SPECIES}

Bello et al. (2005) have very recently provided a review of the geographical distribution in Spain of quarantine nematodes regulated by the European Union (EH Directive 2000/29/EC and/or the EPPO quarantine lists), concluding that only four species (Ditylenchus dipsaci, Globodera pallida, Globodera rostochiensis and Xiphinema rivesi occur in peninsular Spain, and that extensive surveys are needed to delimit the spread of the regulated nematodes and to detect the introduction of exotic quarantine species.

\section{ACKNOWLEDGEMENTS}

The authors are grateful to the following colleagues who provided valuable information on Iberian species: Prof. A Coomans (Ghent, Belgium), Dr. Jiménez-Guirado (Córdoba, Spain), Dr. P.A.A. Loof (Wageningen, the Netherlands) and Dr. T. Bongers (Wageningen, the Netherlands); and thank the financial support received from the projects entitled "Fauna Ibérica: Mononchida and Dorylaimida (in part)" and "Fauna Ibérica: Nematoda: Rhabditida".

\section{References}

Abolafia, J., Guerrero, P., Liébanas, G. \& PeñaSAntiago, R., 2005. Diversidad de rabdítidos (Nematoda, Rhabditida) en cultivos de olivar en la provincia de Jaén. XVI Reunión Bienal de la Real Sociedad Española de Historia Natural (RSEHN), 27 septiembre - 1 octubre, Teruel (España). Fundamental, 6: 31-33.

Abolafia, J., Holovachov, O., Boström, S. \& PeÑaSAntiago, R., 2003. Nematodes of the order Rhabditida from Andalucía Oriental, Spain. The genus Cervidellus Thorne, 1937, (Cephalobidae) with additional data on C. hamatus Thorne, 1937. Nematology, 5: 753-776.

Abolafia, J., Liébanas, G. \& Peña-Santiago, R., 2002. Nematodes of the order Rhabditida from Andalucía Oriental, Spain. The subgenus Pseudacrobeles Steiner, 1938, with a description of a new species. Journal of Nematode Morphology and Systematics, [2001], 4: 137-154.

Abolafia, J. \& Peña-Santiago, R., 2001. Rhabditid species (Nematoda, Rhabditida) recorded in Peninsular Spain and Balearic Islands. Graellsia, 57: 113-131.

Abolafia, J. \& Peña-Santiago, R., 2002. Nematodos del orden Rhabditida de Andalucía Oriental. El género Eucephalobus Steiner, 1936. Graellsia, 58: 59-78.

Abolafia, J. \& PeÑa-Santiago, R., 2003a. Nematodes of the order Rhabditida from Andalucía Oriental, Spain. The genus Acrobeloides (Cobb, 1924) Thorne, 1937, with description of $A$. arenicola sp. n. and a key to species. Journal of Nematode Morphology and Systematics, [2002], 5: 107-130.

Abolafia, J. \& Peña-Santiago, R., 2003b. Nematodes of the order Rhabditida from Andalucía Oriental, Spain. The genus Chiloplacus Thorne, 1937, with description of $C$. maginensis sp. $\mathrm{n}$. and a key to species. Nematology, 5: 243-274.

Abolafia, J. \& PeÑA-SAntiago, R., 2003c. Nematodes of the order Rhabditida from Andalucía Oriental, Spain. The genera Nothacrobeles Allen \& Noffsinger, 1971 and Zeldia Thorne, 1925. Journal of Nematology, 35: 233-243.

Abolafia, J. \& Peña-Santiago, R., 2003d. Nematodes of the order Rhabditida from Andalucía Oriental, Spain. The genus Stegelletina Andrássy, 1984, with description of two new species. Russian Journal of Nematology, 11: 37-53.

Abolafia, J. \& Peña-Santiago, R., 2004. Nematodes of the order Rhabditida from Andalucía Oriental, Spain. The genus Acrobeles von Linstow, 1877 with description of $A$. andalusicus sp. n. and a key to species. Journal of Nematode Morphology and Systematics, [2003], 6: 103-128.

Abolafia, J. \& PeÑa-Santiago, R., 2005. Nematodes of the order Rhabditida from Andalucía Oriental: 
Pseudacrobeles elongatus (de Man, 1880) comb. n. Nematology, 7: 917-926.

Abrantes, I. M. De O., Vovlas, N. \& Santos, M. S. N. DE A., 1992. Host-parasite relationships of Meloidogyne javanica and $M$. lusitanica with Olea europea. Nematologica, 38: 320-327.

Almeida, M. T. M. DE, Santos, M. S. N. De A., Abrantes, I. M. DE O. \& DeCRAEMER, W., 2005. Paratrichodorus divergens sp. n., a new potential virus vector of tobacco rattle virus and additional observations on $P$. hispanus Roca \& Arias, 1986 from Portugal (Nematoda: Trichodoridae). Nematology, 7: 343-361.

Andrássy, I., 2005. Pedozoologica Hungarica No. 3. Free-living neamtodes of Hungary, I. Hungarian Natural History Museum. Budapest. 518 pp.

ARIAS, M. 1979. Distribution of Longidoridae. In: T. J. W. Alphey (ed.). Atlas of plant parasitic nematodes of Spain. European Plant Parasitic Nematode Survey. Dundee: 46-66.

Arias, M., Andrés, M. F. \& Bello, A., 1991. Xiphinema rivesi (Nematoda: Longidoridae) en España. In: J. del Moral de la Vega (ed.). Estudios de Fitopatología. Consejería de Agricultura, Industria y Comercio de Extremadura. Badajoz: 154-159.

Arias, M., Escuer, M., Arcos, S. C. \& Bello, A., 2005. Distribution of Xiphinema pyrenaicum Dalmasso, 1969 with notes on $X$. aceri Chizov, Tiev \& Turkina, 1986 (Nematoda: Longidoridae). Nematology, 7: 45-51.

Arias, M., Escuer, M. \& Bello, A., 2004. Nematodos asociados a madera y árboles de coníferas en pinares españoles. Boletín de Sanidad Vegetal, Plagas, 30 : 581-593.

Arias, M. \& NAVACERRADA, G., 1973. Geographical distribution of Xiphinema Cobb in Spanish vineyards. Nematologia mediterranea, 1: 28-35.

Bello, A., Arias, M., LóPez-PÉrez, J. A., García-ÁlvaReZ, A., Fresno, J., Escuer, M., Arcos, S. C., LaCAsA, A., Sanz, R., Gómez, P., Díez-Rojo, M. A., PiedraBuena, A., Goitia, C., DE LA Horna, J. L. \& MARTínEZ, C. 2004., Biofumigation, fallow, and nematode in vineyard replant. Nematropica, 34: 53-64.

Bello, A., Robertson, L., Díez-Rojo, M. A. \& Arias, M., 2005. A re-evaluation of the geographical distribution of quarantine nematodes reported in Spain. Nematologia mediterranea, 33: 209-216.

Bongers, T., 1988. De Nematoden van Nederland. Natuurhistorische Biliotheek van de Koninklijke Nederlandse Natuurhistiorische Vereniging. Utrecht. 408 pp.

Bongers, T., 2006. Nematoda. In: Fauna Europaea. Database of the non-marine animals of Europe. I www.faunaeur.org /

Bravo, M. A. \& RocA, F., 1995. Observations on Longidorus africanus Merny from Portugal with description of L. vinearum n. sp. (Nematoda: Longidoridae). Fundamental and applied Nematology, 18: 87-94.
Castroviejo, S., 2002. Riqueza florística de la península Ibérica e islas Baleares. El proyecto 'Flora iberica'. In: F. D. Pineda et al. La Diversidad Biológica de España. Prentice Hall. Madrid: 167-174.

Cogolludo, J., 1921. Contribución al conocimiento de las zoocecidias de España. Trabajos del Museo Nacional de Ciencias Naturales, Serie Botánica, 16: 1-117.

Correia, F. J. S. \& Abrantes, I. M. DE O., 2005. Characterization of Heterodera zeae populations from Portugal. Journal of Nematology, 37: 328-335.

DeCraemer, W., 1995. The Family Trichodoridae; Stubby Root and Virus Vector Nematodes. Kluwer Academic Publishers. Dordrecht. 360 pp.

Díez-Rojo, M. A., Bello, A., Escuer, M., LóPez-PÉrez, J. A. \& García-Álvarez, A., 2006. Nematodos fitoparásitos encontrados en Castilla y León. Alternativas no químicas de control. Ministerio de Agricultura, Pesca y Alimentación. Madrid. 254 pp.

Escuer, M., 1995. Els Nematodes. In: El Patrimoni Biològic del Montseny. Catàleg de Flora i Fauna. Servei de Parcs Naturals, Diputació de Barcelona, 2: 17-22.

Escuer, M. \& Bello, A., 2000. Nematodos del género Aphelenchoides de interés fitopatológico y su distribución en España. Boletín de Sanidad Vegetal, Plagas, 26: 47-63.

Escuer, M., LARA, M. P. \& Bello, A., 1999. Distribution of Criconematidae Family in Peninsular Spain and Balearic Islands. International Journal of Nematology, 9: 47-67.

Flores-Romero, P. \& NaVAs, A., 2005. Enhancing taxonomic resolution: distribution dependent genetic diversity in populations of Meloidogyne. Nematology, 7: $517-530$.

Gene, J., Verdejo-Lucas, S., Stchigel, A. M., Sorribas, F. J., \& GuARro, J., 2005. Microbial parasites associated with Tylenchulus semipenetrans in citrus orchards of Catalonia. Biocontrol Science and Techonology, 15: 721-731.

Hernández-Fernández, V., Martín-Barbarroja, J., JiMÉNEZ-DÍAZ, R. M. \& CASTILLO, P., 2005. Reproductive fitness of Meloidogyne artiellia populations on chickpea and durum wheat. Nematology, 7: 243-247.

JiMÉNEZ-GuIRADO, D. \& MurILlo-NAVARRO, R., 2001. Record and description of Dorylaimus popus Gagarin, 1981 (Dorylaimida: Dorylaimidae) from Spain. Journal of Nematode Morphology and Systematics, 4: 39-46.

JimÉnEZ-GuiRADO, D. \& Murillo-NAVARRO, R., 2004. Observations on Lindseyus heterurus (Schuurmans Stekhoven \& Teunissen, 1938) Coomans \& Kheiri, 1986 (Nematoda: Belondiroidea) from Spain. Journal of Nematode Morphology and Systematics, 7: 91-96.

Jiménez-Millán, F., Arias, M., Bello, A. \& LópezPedregal, J. M., 1965. Catálogo de los nematodos fitoparásitos y peri-radiculares encontrados en España. 
Boletín de la Real Sociedad Española de Historia Natural, 63: 47-104.

López-Pérez, J. A., Arias, M. \& Bello, A., 2001. Trichodoridae (Nematoda: Triplonchida) in Spain. Nematology, 3: 403-409.

Martínez-Olías, J., Liébanas, G. M., Guerrero, P., Abolafia, J. \& Peña-Santiago, R., 2005. Sobre la presencia del género Epacrolaimus Andrássy, 2000 (Nematoda: Dorylaimida) en la Península Ibérica. XVI Reunión Bienal de la Real Sociedad Española de Historia Natural (RSEHN), 27 septiembre - 1 octubre, Teruel (España). Fundamental, 6: 121-124.

Murillo-Navarro, R., JimÉnez-Guirado, D., PeñaSantiago, R., LiÉbanas, G. M., Abolafia, J. \& Guerrero, P., 2005. Especies del género Xiphinema Cobb, 1913 (Nematoda: Dorylaimida) en la cuenca del río Guadiamar (provincia de Sevilla). XVI Reunión Bienal de la Real Sociedad Española de Historia Natural (RSEHN), 27 septiembre - 1 octubre, Teruel (España). Fundamental, 6: 143-146.

Navarro, P., Guerrero, F., Pérez-Mellado, V. \& Lluch, J., 1995. Description of a new species: Dorylaimus parasiticus, a parasite of amphibians in the Iberian Peninsula (Nematoda: Dorylaimida). Journal of Zoology, London, 237: 169-177.

Nombela, G., Navas, A. \& Bello, A., 1998. Effects of crop rotations of cereals with vetch and fallow on soil nematofauna in central Spain. Nematologica, 44: 63-80.

OCAÑA, A. \& PicAZO, J. S., 1991. Study on nematode species encountered in the Monachil River (Granada, Spain): Response to organic pollution. Verhandlungen - Internationale Vereinigung für Theoretische und Angewandte Limnologie, 24: 2729-2737.

OrtuÑo, V. M., 2002. Estado de conocimiento de los artrópodos de España. In: F. D. Pineda et al. La Diversidad Biológica de España. Prentice Hall. Madrid: 209-234.

País, C. S. \& Abrantes, I. M. DE O., 1989. Esterase and malate dehydrogenase phenotypes in Portuguese populations of Meloidogyne species. Journal of Nematology, 21: 342-346.

Penas, A. C., Correia, P., Bravo, M. A., Mota, M. \& Tenreiro, R., 2004. Species of Bursaphelenchus Fuchs, 1937 (Nematoda: Parasitaphelenchidae) associated with maritime pine in Portugal. Nematology, 6: $437-453$

Peña-Santiago, R., Abolafia, J., Hernández, M. A., JimÉnEZ-Guirado, D. \& OCAÑA, A., 2005. Soil and freshwater nematodes (Nematoda) of the orders Enoplida, Triplonchida, Mononchida, Chromadorida, Desmodorida, Monhysterida, Araeolaimida, Plectida and Aphelenchida recorded in the Iberian Peninsula and the Balearic Islands: A compendium. Monographic papers on Nematology $n^{\circ} 3$. Servicio de Publicaciones. Universidad de Jaén. 91 pp.
Peña-Santiago, R., Abolafia, J., Liébanas, G., Peralta, M. \& Guerrero, P., 2003. Dorylaimid species (Nematoda, Dorylaimida) recorded in the Iberian Peninsula and the Balearic Islands: A compendium. Monographic papers on Nematology $n^{\circ} 1$. Servicio de Publicaciones. Universidad de Jaén. 100 pp.

Peña-Santiago, R., Castillo, P., Escuer, M., Guerrero, P., TAlaVera, M. \& Vieira, P., 2004. Tylenchid species (Nematoda, Tylenchida) recorded in the Iberian Peninsula and the Balearic Islands: A compendium. Monographic papers on Nematology $n^{\circ} 2$. Servicio de Publicaciones. Universidad de Jaén. 100 pp.

Peña-Santiago, R., Jiménez-Guirado, D., LiéBanas, G., Murillo, R., Abolafia, J. \& Guerrero, P., 2003. Balance provisional del estado de la nematofauna en la cuenca del río Guadiamar y del proceso de restauración de la comunidad edáfica en las zonas afectadas por el vertido tóxico. In: Ciencia y Restauración del Río Guadiamar. Resultados del Programa de Investigación del Corredor Verde del Guadiamar 1998-2002. Consejería de Medio Ambiente, Junta de Andalucía. Sevilla: 378-384.

Peña-Santiago, R., Jiménez-Guirado, D., Liébanas, G., Murillo, R., Abolafia, J. \& Guerrero, P., 2005. Study of the nematode fauna (Dorylaimida and Mononchida) in affected areas of the Guadiamar River basin: preliminary results. In: T. A. Delvalls \& J. BlASCO (eds.). Integrated assessment and management of the ecosystems affected by the Aznalcollar mining spill (sw Spain). Cátedra UNESCO/Unitwin. Cádiz: 99-104.

Ramos, M. A., Lobo, J. M. \& Esteban, M., 2002. Riqueza faunística de la península Ibérica e islas Baleares. El proyecto 'Fauna iberica'. In: F. D. Pineda et al. La Diversidad Biológica de España. Prentice Hall. Madrid: 197-207.

Romero, M. D., Bello, A. \& Arias, M., 1973. The genus Heterodera Schmidt in Spain. Nematologia mediterranea, 1: 83-91.

Smythies, B. E., 1984-1986. Flora of Spain and the Balearic Islands. Checklist of Vascular Plants. Englera, 3(1): 1-212; 3(2): 213-486; 3(3): 487-880.

TAYlor, C. E. \& Brown, D. J. F., 1997. Nematode Vectors of Plant Viruses. CAB International. Wallingford. $286 \mathrm{pp}$.

Vives-Moreno, A., 1994. Catálogo sistemático y sinonímico de los lepidópteros de la Península Ibérica y Baleares (Insecta: Lepidoptera) (Segunda Parte). Ministerio de Agricultura, Pesca y Alimentación. Madrid. $\mathrm{x}+775 \mathrm{pp}$. 
Appendix 1.- List of new species for the Iberian fauna included in this compilation ${ }^{1}$ [ordered by genus name].

Apéndice 1.- Lista de nuevas especies de fauna ibérica incluidas en este trabajo ${ }^{1}$ [ordenadas por géneros].

\section{Order Dorylaimida}

Dorylaimus parasiticus Navarro, Guerrero, Pérez-Mellado \& Lluch, 1995*

Dorylaimus popus Gagarin, 1981

Epacrolaimus declinatoaculeatus (Kreis, 1924) Andrássy, 2000²

Longidorus africanus Merny, 1966

Longidorus vinearum Bravo \& Roca, 1995*

Xiphinema setariae Luc, $1958^{2}$

\section{Order Rhabditida}

Acrobeles andalusicus Abolafia \& Peña-Santiago, 2004* Acrobeles cylindricus Ivanova, 1968

Acrobeloides arenicola Abolafia \& Peña-Santiago, 2003* Acrobeloides bodenheimeri (Steiner, 1936) Thorne, 1937 Acrobeloides setosus Brzeski, 1962

Cervidellus hamatus Thorne, 1937

Chiloplacus demani (Thorne, 1925) Thorne, 1937

Chiloplacus maginensis Abolafia \& Peña-Santiago, 2003* Chiloplacus magnus Rashid \& Heyns, 1990

Chiloplacus tenuis Rashid et Heyns, 1990

Chiloplacus trilineatus Steiner, 1940

Eucephalobus hooperi Marinari-Palmisano, 1967
Nothacrobeles lanceolatus Abolafia \& Peña-Santiago, 2003* Nothacrobeles lunensis Shahina \& De Ley, 1997

Pseudacrobeles (Pseudacrobeles) eurystoma (Andrássy, 1967) Abolafia, Liébanas \& Peña-Santiago, 2002

Pseudacrobeles (Pseudacrobeles) tabacum (Rashid, Geraert \& Sharma, 1985) De Ley, Siddiqi \& Boström, 1993

Pseudacrobeles (Pseudacrobeles) unguicolis Abolafia, Liébanas \& Peña-Santiago, 2002*

Pseudacrobeles (Pseudacrobeles) variabilis (Steiner, 1936) Steiner, 1938

Stegelletina pygmaea Abolafia \& Peña-Santiago, 2003* Stegelletina salinaria Abolafia \& Peña-Santiago, 2003*

Zeldia punctata (Thorne, 1925) Thorne, 1937

\section{Order Triplonchida}

Paratrichodorus divergens Almeida, Santos, Abrantes \& Decraemer, 2005

\section{Order Tylenchida}

Anguina graminis (Ardí, 1950) Filipjev, 1936

Ogma murrayi Southern, 1914

${ }^{\text {'}}$ For their taxonomical position, see previous papers.

2 Previously recorded with another name (see above).

* (Provisional) Iberian endemisms. 
Appendix 2.- - List of Iberian species (ordered alphabetically by specific name; in brackets the corresponding nematode order: $\mathrm{Aph}=$ Aphelenchida, $\mathrm{Chr}=$ Chromadorida, Des $=$ Desmodorida, Dor $=$ Dorylaimida, Eno $=$ Enoplida, Mon $=$ Mononchida, Moy $=$ Monhysterida, $\mathrm{Ple}=$ Plectida, $\mathrm{Rha}=$ Rhabditida, $\mathrm{Tri}=$ Triplonchida, $\mathrm{Tyl}=$ Tylenchida; $*$ provisional Iberian endemism $)$.

Apéndice 2. - Lista de especies ibéricas (ordenadas alfabéticamente por las denominaciones específicas; se indica entre paréntesis el orden correspondiente: $\mathrm{Aph}=$ Aphelenchida, $\mathrm{Chr}=$ Chromadorida, Des $=$ Desmodorida, Dor $=$ Dorylaimida, Eno $=$ Enoplida, Mon = Mononchida, Moy $=$ Monhysterida, Ple $=$ Plectida, Rha $=$ Rhabditida, Tri $=$ Triplonchida, Tyl $=$ Tylenchida $*$ endemismo ibérico provisional).

aberrans, Basiria $(\mathrm{Tyl})(1)$

aberrans, Mesodorylaimus (Dor) (1) abrantinum, Xiphinema (Dor) (4) (*) acarayensis, Malenchus (Malenchus) (Tyl) (4) accentuatus, Tylencholaimus (Dor) spec. inquir: (2)

aceri, Xiphinema (Dor) (4)

acris, Nothotylenchus (Tyl) (2)

acris, Prodorylaimus (Dor) (4)

acristylus, Paratrophurus (Tyl) (4)

acuminatus, Plectus (Ple) (4)

acuticauda, Eudorylaimus (Dor) (2)

acuticaudatus, Paravulvus (Dor) (1)

acutus, Alaimus (Eno) (1)

acutus, Anatonchus (Mon) (4)

acutus, Nothotylenchus (Tyl) (1)

acutus, Paratrichodorus (Tri) (1)

adasi, Nothotylenchus (Tyl) (1)

adriaani, Aporcelaimellus (Dor) (1)

aduncus, Tylenchorhynchus (Tyl) (3)

aegypticus, Mesodorylaimus (Dor) (1)

aenariensis, Geomonhystera (Moy) (1)

aequalis, Trichodorus (Tri) (1)

aerolatus, Bitylenchus (Tyl) (4)

affinis, Nagelus (Tyl) (1)

affinis, Nothotylenchus (Tyl) (1)

affinis, Tripyla (Tri) (3)

afghanicus, Dorylaimus (Dor) (1)

africana, Monhystera (Moy) (4)

africanus, Longidorus (Dor) (4)

agilis, Theristus (Moy) (1)

agricola, Aglenchus (Tyl) (4)

agricolus, Discolaimus (Dor) (4)

alacinatus, Coslenchus (Tyl) (4)

alboranensis, Merlinius (Tyl) (4)

aljabaranus, Allodorylaimus (Dor) (4) $(*)$

alkani, Pratylenchoides (Tyl) (4)

allieri, Ogma (Seriespinula) (Tyl) (4)

alvegus, Longidorus (Dor) (4) (*)

americanus, Mesodorylaimus (Dor) (1)

americanus, Tylencholaimus (Dor) (1)

amorphus, Criconemoides (Criconemoides)

(Tyl) (4)

amplus, Amplimerlinius (Tyl) (4) (*)

amylovorus, Aporcelaimellus (Dor) (3)

anchilisposoma, Safianema (Tyl) (1)

andalusicus, Acrobeles (Rha) (4) (*)

andinus, Tylocephalus (Ple) (4)

andrassyi, Allodorylaimus (Dor) (1)

andrassyi, Eumonhystera (Moy) (4)

andrassyi, Filenchus (Tyl) (1)

andrassyi, Malenchus (Malenchus) (Tyl) (1)

andrassyi, Plectus (Ple) (1)

anemones, Paratrichodorus (Tri) (3)

angeloi, Labronema (Dor) (1)

angleus, Microdorylaimus (Dor) (2)

angusticephalus, Filenchus (Tyl) (1) anneckei, Nygolaimus (Dor) (4)

annulata, Macroposthonia (Tyl) (1)

annulatiformis, Macroposthonia (Tyl) (4)

annulatus, Aporcelaimus (Dor) spec. inquir. (2)

annulatus, Plectus (Ple) (4)

annuliferum, Criconema (Criconema) (Tyl) (4)

antipolitana, Macroposthonia (Tyl) (4)

aonli, Paratylenchus (Gracilacus) (Tyl) (1)

aorolaimoides, Hoplolaimus (Hoplolaimus)

(Tyl) (4) (*)

apitica, Belondira (Dor) (1)

aquaticum, Tantunema (Dor) (3)

aquaticus, Aphanolaimus (Ple) (4)

aquaticus, Aquatides (Dor) (4)

aquaticus, Makatinus (Dor) (4) (*)

aquaticus, Mononchus (Mon) (4)

aquaticus, Rhabdolaimus (Ple) (4)

aquatilis, Plectus (Ple) (1)

aquilonius, Filenchus (Tyl) (4)

arctica, Prodesmodora (Des) (1)

arcticum, Ereptonema (Ple) (4)

arcuatus, Dorylaimoides (Dor) (4)

arcuatus, Tylenchus (Tyl) (1)

arcuicaudatus, Dorylaimellus (Dor) (4) (*)

arculatus, Paratylenchus (Paratylenchus)

(Tyl) (4)

arcus, Eudorylaimus (Dor) (3)

arenaria, Meloidogyne (Tyl) (4)

arenarius, Trophotylenchulus (Tyl) (4)

arenicola, Acrobeloides (Rha) (4) (*)

ariasae, Dorylaimoides (Dor) (4) (*)

aridus, Deladenus (Tyl) (1)

armatus, Plectus (Ceratoplectus) (Ple) (4)

artiellia, Meloidogyne (Tyl) (3)

assamensis, Alaimus (Eno) (1)

assimilis, Plectus (Ceratoplectus) (Ple) (4)

asymphidorus, Dorylaimus (Dor) (4)

attentus, Aphanolaimus (Ple) (2)

attenuatus, Chrysonema (Dor) (2)

attenuatus, Longidorus (Dor) (3)

auriculatus, Tylocephalus (Ple) (4)

auringiensis, Tylencholaimellus (Dor) (4) (*)

ausafi, Ditylenchus (Tyl) (1)

australis, Geomonhystera (Moy) (3)

avenae, Aphelenchus (Aph) (4)

avenae, Heterodera (Tyl) (4)

avolai, Talanema (Dor) (3)

axei, Rhabditis (Rha) (2)

baetica, Meloidogyne (Tyl) (4) (*) baeticus, Dorylaimoides (Dor) (4) (*) baeticus, Mesodorylaimus (Dor) (4) (*) baeticus, Miconchus (Mon) (4) (*) baeticus, Nygolaimus (Dor) (4) (*)

baldaccii, Paratylenchus (Paratylenchus)

(Tyl) (3)

bambus, Cylindrolaimus (Ara) (4) banaticus, Carcharodiscus (Dor) (4)

barbata, Eumonhystera (Moy) (4)

barcinai, Funaria (Dor) (4) (*)

bastiani, Mesodorylaimus (Dor) (4)

beirensis, Trichodorus (Tri) (4) (*)

belloi, Longidorus (Dor) (4) (*)

belmontense, Xiphinema (Dor) (4) (*)

bernensis, Paroigolaimella (Rha) (3)

bicaudatus, Aphelenchoides (Aph) (2)

bicostatus, Neodolichorhynchus (Neodolicho-

rhynchus) (Tyl) (4) $(*)$

bifasciatus, Uliginotylenchus (Tyl) (1)

bisimilis, Heterocephalobus (Rha) (1)

blastophthorus, Aphelenchoides (Aph) (3)

bodenheimeri, Acrobeloides (Rha) (4)

bombilectus, Eudorylaimus (Dor) (3)

borealis, Rotylenchulus (Tyl) (3)

brachyuris, Mylonchulus (Mon) (4)

brachyuris, Nygolaimus (Dor) (4)

brachyurus, Scutellonema (Tyl) (3)

brassicae, Ditylenchus (Tyl) (1)

brassicae, Tylenchorhynchus (Tyl) (1)

brevicaudatus, Mesodorylaimus (Dor) (4) (*)

brevicaudatus, Mylonchulus (Mon) (3)

brevicaudatus, Rotylenchus (Tyl) (1)

brevicolle, Diphtherophora (Tri) (1)

brevicolle, Xiphinema (Dor) (3)

brevidens, Merlinius (Tyl) (3)

brevidentatus, Enchodelus (Paraenchodelus) (Dor) (3)

brevilineatus, Bitylenchus (Tyl) (3)

brevis, Eudorylaimus (Dor) (2)

brevisicum, Xiphinema (Dor) (4) (*)

brigdammensis, Prodorylaimus (Dor) (4)

bryanti, Malenchus (Malenchus) (Tyl) (1)

bryophila, Dorydorella (Dor) (2)

bryophilus, Malenchus (Malenchus) (Tyl) (2)

brzeskii, Mesodorylaimus (Dor) (4) (*)

buckleyi, Nothotylenchus (Tyl) (1)

buetschlii, Acrobeloides (Rha) (4)

bulbiferus, Discolaimoides (Dor) (4)

bulgaricum, Tylolaimophorus (Tri) (3)

butteus, Filenchus (Tyl) (3)

buxophilus, Rotylenchus (Tyl) (1)

cadavalense, Xiphinema (Dor) (4) (*)

caespiticola, Longidorus (Dor) (3)

camachoi, Pratylenchoides (Tyl) (4) (*)

camelliae, Nagelus (Tyl) (3)

cameroonensis, Chronogaster (Ple) (4)

canadensis, Helicotylenchus (Tyl) (3)

cancellatus, Coslenchus (Tyl) (3)

cancellatus, Plectus (Ple) (4)

cantabricus, Prodorylaimus (Dor) (4) (*)

capitatus, Quinisulcius (Tyl) (3)

capsici, Aorolaimus (Tyl) (4)

carinata, Oigolaimella (Rha) (3) 
carmenae, Paraxonchium (Dor) (4) (*) carolinensis, Helicotylenchus (Tyl) (1) carotae, Heterodera (Tyl) (1) carpetanensis, Longidorus (Dor) (4) (*) carteri, Eudorylaimus (Dor) (2) castellanum, Ogma (Ogma) (Tyl) (4) catharinae, Rotylenchus (Tyl) (3) cavensis, Mylonchulus (Mon) (2) cazorlaensis, Rotylenchus (Tyl) (4) (*) centrocercus, Eudorylaimus (Dor) (4) cephalatus, Discomyctus (Dor) (1) cervus, Cervidellus (Rha) (1) chitwoodi, Bursaphelenchus (Aph) (3) chitwoodi, Meloidogyne (Tyl) (3) chlorurus, Odontolaimus (Ple) (4) ciccaronei, Paratylenchus (Paratylenchus) (Tyl) (4)

ciliatus, Acrobeles (Rha) (4)

cinctus, Tylencholaimellus (Dor) (4) circulata, Prodesmodora (Des) (4) circulifer, Thonus (Dor) (1) cirratus, Plectus (Ple) (4) civellae, Crossonema (Tyl) (4) clarki, Filenchus (Tyl) (1) clarus, Tylenchorhynchus (Tyl) (4) clavatus, Pungentus (Dor) (1) clavicaudata, Boleodorus (Tyl) (1) clavicaudatus, Clavicaudoides (Dor) (4) clavicaudatus, Mesodorylaimus (Dor) (4) closlongicaudatus, Semitobrilus (Tri) (4) cobbi, Ogma (Seriespinula) (Tyl) (4) cocophillus, Hemicriconemoides (Tyl) (3) coffeae, Pratylenchus (Tyl) (3) communis, Cylindrolaimus (Ara) (3) communis, Diphtherophora (Tri) (2) complexus, Acrobeles (Rha) (4) composticola, Aphelenchoides (Aph) (4) confusus, Dorylaimoides (Dor) (4) (*) congoensis, Longidorus (Dor) (4) conicaudatus, Eudorylaimus (Dor) (1) conicaudatus, Tylencholaimus (Dor) (4) (*) conida, Hemicycliophora (Tyl) (4) consobrinum, Prothallonema (Tyl) (2) consobrinus, Epidorylaimus (Dor) (1) constrictus, Tylencholaimus (Dor) (4) coomansi, Drilocephalobus (Rha) (3) cornis, Eucephalobus (Rha) (1) cornuta, Tripyla (Tri) (2) coronatus, Diploscapter (Rha) (3) coronatus, Tylencholaimellus (Dor) (1) costatus, Coslenchus (Tyl) (4) costatus, Teratocephalus (Rha) (4) coxi europaeum, Xiphinema (Dor) (4) crassidens, Metateratocephalus (Ple) (1) crassus, Laimydorus (Dor) (4) crataegi, Longidorus (Dor) (4) (*) crenacauda, Helicotylenchus (Tyl) (3) crenata, Macroposthonia (Tyl) (4) crenatus, Pratylenchus (Tyl) (3) crenicauda, Pratylenchoides (Tyl) (4) crotaloides, Criconema (Criconema) (Tyl) (4) cruciferae, Heterodera (Tyl) (4) curvata, Macroposthonia (Tyl) (4) curvicaudata, Cephaloboides (Rha) (3) curvitatus, Paratylenchus (Paratylenchus) (Tyl) (1)

curvus, Quinisulcius (Tyl) (3)

cyatolaimus, Actinolaimus (Dor) (1) cylindricaudatus, Dorylaimoides (Dor) (4) (*) cylindricum, Tylolaimophorus (Tri) (2) cylindricus, Acrobeles (Rha) (4) cylindricus, Nothotylenchus (Tyl) (3) cylindricus, Trichodorus (Tri) (4) cylindricus, Tylenchorhynchus (Tyl) (1) cyperi, Heterodera (Tyl) (4)

dadayi, Teratocephalus (Rha) (4) dalmassoi, Protodorylaimus (Dor) (4) danubialis, Nothotylenchus (Tyl) (1) davainei, Tylenchus (Tyl) (4) decalineatus, Atetylenchus (Tyl) (1) declinatoaculeatus, Epacrolaimus (Dor) (4) delgadoi, Domorganus (Ple) (4) (*) deliblatica, Longidorella (Dor) (1) demani, Chiloplacus (Rha) (4)

demani, Criconema (Nothocriconemella) (Tyl) (4)

demonstrans, Campydora (Eno) (3) devimucronata, Stegelletina (Rha) (2) dhanachandi, Alaimus (Eno) (1) dherdei, Macroposthonia (Tyl) (4) diffusum, Xiphinema (Dor) (4) digonicus, Helicotylenchus (Tyl) (3) dihystera, Helicotylenchus (Tyl) (3) dihysteroides, Helicotylenchus (Tyl) (4) (*) dipsaci, Ditylenchus (Tyl) (4) discolaimoideus, Discolaimium (Dor) (2) discrepans, Ottolenchus (Tyl) (4) discretus, Discotylenchus (Tyl) (3) dispar, Eumonhystera (Moy) (4) dissimile, Xiphinema (Dor) (4) (*) divergens, Paratrichodorus (Tri) (4) (*) diversicaudatum, Xiphinema (Dor) (4) diversum, Xiphinema (Dor) (4) (*) diversus, Nygolaimus (Dor) (4) (*) dolichurus, Anatonchus (Mon) (4) dolichurus, Paramphidelus (Eno) (2) dolichurus, Prismatolaimus (Tri) (4) drepanoideus, Microdorylaimus (Dor) (1) dubium, Daptonema (Moy) (4) dubium, Discolaimium (Dor) (3) dubius, Bitylenchus (Tyl) (4) dumnonicus, Halenchus (Tyl) (3) duplexa, Basiria (Tyl) (4) duplicivestitum, Criconema (Criconema) (Tyl) (4) duriense, Xiphinema (Dor) (4) (*) durus, Deladenus (Tyl)

\section{$\mathbf{E}$}

editorius, Alaimus (Eno) (1) eggersi, Bursaphelenchus (Aph) (4) egmonti, Dorylaimellus (Dor) (3) elaboratus, Acrobeles (Rha) (1) elegans, Ironus (Eno) (4) elegans, Thonus (Dor) (1) elegans, Tylenchus (Tyl) (1) elegantulus Filenchus (Tyl) (4) elongatum, Xiphinema (Dor) (1) elongatus, Pseudacrobeles (Pseudacrobeles) (Rha) (4)

elongatus, Longidorus (Dor) (1) elongatus, Plectus (Ple) (1) emarginatus, Acrolobus (Rha) (2) enatus, Paratylenchus (Gracilacus) (Tyl) (1) enckelli, Boreolaimus (Dor) (1) engadinensis, Pungentus (Dor) (3) epacris, Pratylenchoides (Tyl) (1) epicharoides, Hemicycliophora (Tyl) (3) eremitus, Aphelenchus (Aph) (1) eroshenkoi, Takamangai (Dor) (3) erythrinae, Helicotylenchus (Tyl) (3) ettersbergensis, Takamangai (Dor) (4) europaeus, Nygolaimus (Dor) (4) eurydorys, Aporcelaimus (Dor) (1) eurystoma, Pseudacrobeles (Pseudacrobeles)

(Rha) (4)

ewingi, Tylenchorhynchus (Tyl) (1) exallus, Helicotylenchus (Tyl) (3) exiguus, Tylenchus (Tyl) (1) exile, Xiphinema (Dor) (4) (*) eximius, Carcharodiscus (Dor) (4) (*) eximius, Rotylenchus (Tyl) (4) exinocaudatus, Plectus (Ple) (4)

facetus, Panagrolaimus (Rha) (1) fagi, Proleptonchus (Dor) (4) (*) fagini, Ogma (Ogma) (Tyl) (4) (*) fallax, Pratylenchus (Tyl) (3) ferniae, Macroposthonia (Tyl) (1) ferox, Labronema (Dor) (1) ferrandini, Aphelenchoides (Aph) (1) fici, Heterodera (Tyl) (4) fictor, Fictor (Rha) (1)

filiarum, Prodorylaimus (Dor) (4) filicaudata, Monhystera (Moy) (1) filicaudata, Tripyla (Tri) (4) filiformis, Chrysodorus (Dor) (2) filiformis, Discolaimoides (Dor) (1) filiformis, Eumonhystera (Moy) (4) filiformis, Filenchus (Tyl) (4) filiformis, Protorhabditis (Rha) (2) fimbriatum, Crossonema (Tyl) (4) flandriensis, Basiria (Tyl) (1) flexus, Drepanodorylaimus (Dor) (1) foetida, Tylopharynx (Rha) (4) fragariae, Aphelenchoides (Aph) (4) franklinae, Coslenchus (Tyl) (1) frontiniani, Longidorella (Dor) (1) fungivorus, Bursaphelenchus (Aph) (4) fusiformis, Malenchus (Malenchus) (Tyl) (1)

G

gaddi, Hemicriconemoides (Tyl) (3) gadeai, Pratylenchoides (Tyl) (4) gadeai, Tylenchorhynchus (Tyl) spec. inquir. (1) galeatus, Hoplolaimus (Hoplolaimus) (Tyl) (1) galeatus, Merlinius (Tyl) spec. inquir. (1) geophilus, Plectus (Ple) (4) geraerti, Nothotylenchus (Tyl) (3) gersoni, Xiphinema (Dor) (4) (*) giennense, Axonchium (Dor) (4) (*) giennensis, Trichodorus (Tri) (4) (*) ginglymodontus, Anatonchus (Mon) (4) globatus, Dorylaimellus (Dor) (4) globigerus Amplimerlinius (Tyl) (3) globulicola, Pratylenchus (Tyl) (1) glomerans, Tripyla (Tri) (4) goettingiana, Heterodera (Tyl) (4) goffarti, Bitylenchus (Tyl) (3) goffarti, Rhodolaimus (Rha) (4) goodeyi, Longidorus (Dor) (3) goodeyi, Paratylenchus (Gracilacus) (Tyl) (4) goodeyi, Rotylenchus (Tyl) (2) gracilicaudatus, Anatonchus (Mon) (1) 
gracilidens, Rotylenchus (Tyl) (3) gracilis, Achromadora (Chr) (4) (*) gracilis, Basiria (Tyl) (3)

gracilis, Bastiania (Ple) (3) gracilis, Chitwoodiellus (Dor) (4) (*) gracilis, Hirschmanniella (Tyl) (4) gracilis, Tobrilus (Tri) (4) graciloides, Brevitobrilus (Tri) (4) graciloides, Metadiplogaster (Rha) (1) graminis, Anguina (Tyl) (1) graminophila, Basiria (Tyl) (3) granatensis, Brevitobrilus (Tri) (4) (*) grandipapillatus, Eutobrilus (Eut.) (Tri) (4) grandis, Dorylaimoides (Dor) (4) $(*)$ grandis, Xiphinema (Dor) spec. inquir. (1) granuliferus, Allodorylaimus (Dor) (3) granulosus, Anaplectus (Ple) (4) granulosus, Leptonchus (Dor) (4) guevarai, Zygotylenchus (Tyl) (4) guidettii, Aprutides (Aph) (3)

hamatus Filenchus (Tyl) (3)

hamatus, Cervidellus (Rha) (4)

hapla, Meloidogyne (Tyl) (4)

hartingii, Paravulvus (Dor) (3)

hastata, Monhystrella (Moy) (4)

hellenicus, Bursaphelenchus (Aph) (4)

helveticus, Dorylaimus (Dor) (4)

heterurus, Lindseyus (Dor) (4)

hexincisus, Pratylenchus (Tyl) (3)

heynsi, Chitwoodiellus (Dor) (4) (*)

heynsi, Sectonema (Dor) (1)

hilarulus, Psilenchus (Tyl) (3)

hilarus, Psilenchus (Tyl) (1)

hispalensis, Macroposthonia (Tyl) (4)

hispanica, Meloidogyne (Tyl) (4) (*)

hispanica, Vanderlindia (Dor) (4) (*)

hispanicus, Dorylaimoides (Dor) (4) (*)

hispanicus, Margollus (Dor) (4)

hispaniensis, Pratylenchoides (Tyl) (4) (*)

hispanus, Paratrichodorus (Tri) (4) (*)

hispidum, Xiphinema (Dor) (4) $\left(^{*}\right)$

hoffmaenneri, Mesodorylaimus (Dor) (1)

hofmanni, Bursaphelenchus (Aph) (1)

holdemanni, Allodorylaimus (Dor) (4)

hooperi, Eucephalobus (Rha) (4)

hopedorus, Enchodelus (Enchodelus) (Dor) (1)

hornensis, Amplimerlinius (Tyl) (4) (*)

hortensis, Paramphidelus (Eno) (1)

huesingi, Bitylenchus (Tyl) (4)

humilis, Epidorylaimus (Dor) (1)

humuli, Heterodera (Tyl) (4)

hungarica, Eumonhystera (Moy) (3)

hungarica, Ogma (Seriespinula) (Tyl) (4)

hygrophilus, Panagrolaimus (Rha) (1)

hylobianum, Bursaphelenchus (Aph) (4)

iberica, Hemicycliophora (Tyl) (4) (*) ibericus, Mesodorylaimus (Dor) (4) $\left(^{*}\right)$ ibericus, Tylencholaimus (Dor) (4) (*) iberis, Paralongidorus (Dor) (4) $(*)$ icarus, Amplimerlinius (Tyl) (3) ignavus, Ironus (Eno) (4) imberbis, Tobrilia (Tri) (1) impar, Helicotylenchus (Tyl) (1) imperialis, Trophurus (Tyl) (4) incognita, Meloidogyne (Tyl) (4) incultus, Rotylenchus (Tyl) (3)

index, Xiphinema (Dor) (4)

indicus, Telotylenchus (Tyl) (3)

inermis, Rhabditoides (Rha) (1)

iners, Eudorylaimus (Dor) (2)

inflatus, Mylonchulus (Mon) (3)

informis, Criconemoides (Criconemoides)

(Tyl) (4)

ingens, Xiphinema (Dor) (3)

insolitum, Phallaxonchium (Dor) (4)

intermedia, Tripylella (Tri) (4)

intermedius, Amplimerlinius (Tyl) (4) (*)

intermedius, Aquatides (Dor) (2)

intermedius, Ditylenchus (Tyl) (4)

intermedius, Longidorus (Dor) (4)

intermedius, Paracyatholaimus (Chr) (4)

intermedius, Prismatolaimus (Tri) (4)

intermedius, Tylencholaimus (Dor) (4) (*)

intertextus, Pungentus (Dor) (1)

iranica, Monhystrella (Moy) (1)

iranicus, Psilenchus (Tyl) (1)

irregularis, Macroposthonia (Tyl) (4)

italiae, Xiphinema (Dor) (4)

$\mathbf{J}$

jacobi, Dorylaimellus (Dor) (4)

javanica, Meloidogyne (Tyl) (4)

joctus, Merlinius (Tyl) (2)

junctus, Eudorylaimus (Dor) (1)

jurassicus, Eudorylaimus (Dor) (1)

kaszabi, Takamangai (Dor) (1)

kenyensis, Prismatolaimus (Tri) (4)

krugi, Xiphinema (Dor) (1)

$\mathbf{L}$

labiatus, Cephalobus (Rha) (1) labiatus, Discolaimus (Dor) (4) (*)

labiatus, Metaporcelaimus (Dor) (2) laevicapitatus, Longidorus (Dor) (1) lafoense, Xiphinema (Dor) (4) (*) lagrecai, Amphidelus (Eno) (3) lamellatum, Criconema (Criconema) (Tyl) (1) lamelliferus, Neodolichorhynchus (Mulkorhynchus) (Tyl) (4) lanceolatum, Xiphinema (Dor) (4) (*)

lanceolatus, Nothacrobeles (Rha) (4) (*) lapidosum, Xiphinema (Dor) (4) (*) lateralis, Coslenchus (Tyl) (1)

latipons, Heterodera (Tyl) (4) latus, Heterocephalobus (Rha) (1) leichenicola, Tylaphelenchus (Aph) (2) leiocauda, Pratylenchoides (Tyl) (3) lenorus, Scutylenchus (Tyl) (3)

leoni, Bursaphelenchus (Aph) (4) lepidura, Monhystrella (Moy) (4) leptocephalus, Paraxonchium (Dor) (3) leptolaimus, Prismatolaimus (Tri) (4) leptosoma, Lelenchus (Tyl) (2) leptus, Alaimus (Eno) (1) leptus, Nagelus (Tyl) (1) leuckarti, Chromadorita (Chr) (4) leuckarti, Eudorylaimus (Dor) (3) lheritieri, Pristionchus (Rha) (1) lieberi, Basirotyleptus (Dor) (4) limberi, Aphelenchoides (Aph) (1) limnophilus, Dorylaimoides (Dor) (4) limnophilus, Rhabdolaimus (Ple) (4) lineatus, Dorylaimus (Dor) (1)

litoralis, Mesodorylaimus (Dor) (3)

longicauda, Amplimerlinius (Tyl) (4) (*)

longicaudata, Bastiania (Ple) (2)

longicaudata, Rhabditis (Rha) (1) longicaudatoides, Prodorylaimus (Dor) (4)

longicaudatula, Eumonhystera (Moy) (4)

longicaudatus, Belonolaimus (Tyl) (1) longicaudatus, Chrysodorus (Dor) (4)

longicaudatus, Miconchus (Mon) (4) (*) longicaudatus, Plectus (Ple) (4) longicaudatus, Prodorylaimus (Dor) (1) longicaudatus, Tylencholaimus (Dor) (4) (*) longicollis, Microdorylaimus (Dor) (4) longidens, Pungentus (Dor) (4) longidoroides, Xiphinema (Dor) (1) longistilum, Xiphinema (Dor) (4) (*) loofi, Criconema (Criconema) (Tyl) (4) loofi, Paratrophurus (Tyl) (4) loofi, Paraxonchium (Dor) (1) loofi, Pseudacrobeles (Bunobus) (Rha) (1) loofi, Tylencholaimellus (Dor) (4) lugdunensis, Epidorylaimus (Dor) (4) lunensis, Nothacrobeles (Rha) (2) lupini, Xiphinema (Dor) (4) (*) lusitanica, Meloidogyne (Tyl) (4) (*) lusitanicum, Xiphinema (Dor) (4) $(*)$ lusitanicus, Longidorus (Dor) (4) (*) lusitanicus, Trichodorus (Tri) (4) (*) lutonense, Safianema (Tyl) (1) lutosa, Hemicycliophora (Tyl) (3)

$\mathbf{M}$

machadoi, Malenchus (Malenchus) (Tyl) (1) macramphis, Longidorella (Dor) (4) macrobrachyuris, Nygolaimus (Dor) (1) macrodorus, Enchodelus (Enchodelus) (Dor) (1) macrodorus, Hemicriconemoides (Tyl) (4) (*) macrodorus, Paratylenchus (Gracilacus) (Tyl) (3)

macrodorus, Xenocriconemella (Tyl) (4) macrolaimus, Paractinolaimus (Dor) (4) macrosoma, Dorylaimus (Dor) (4) (*) macrosoma, Longidorus (Dor) (3) macrosoma, Rotylenchulus (Tyl) (4) macrura Monhystrella (Moy) (4) macrurus, Amplimerlinius (Tyl) (4) madeirense, Xiphinema (Dor) (4) magadani, Plectus (Ple) (1) maginensis, Chiloplacus (Rha) (4) (*) magnicauda, Pratylenchoides (Tyl) (3) magnidens, Neopsilenchus (Tyl) (4) magnistylus, Amplimerlinius (Tyl) (4) (*) magnus jaeni, Rotylenchus (Tyl) (4) magnus magnus, Rotylenchus (Tyl) (4) magnus, Alaimus sp. inq.] (Eno) (*) magnus, Chiloplacus (Rha) (4) major, Discolaimus (Dor) (4) malacitanus, Mesodorylaimus (Dor) (4) (*) mamillatus, Aporcelaimellus (Dor) (1) mamillatus, Scutylenchus (Tyl) (4) (*) manalicum, Axonchium (Axonchium) (Dor) (1) mani, Heterodera (Tyl) (4) mariae, Discolaimus (Dor) (4) (*) marioni, Meloidogyne (Tyl) (3) mas, Prodorylaimus (Dor) (4) maupasi, Rhabditis (Rha) (2) mauritiense, Labronema (Dor) (1) maximus, Paralongidorus (Dor) (1) 
maximus, Sauertylenchus (Tyl) (4) media, Eumonhystera (Moy) (4) (*) mediana, Takamangai (Dor) (1) medians, Nothotylenchus (Tyl) (3) mediterranea, Heterodera (Tyl) (3) melancholicus, Cylindrolaimus (Ara) (1) meyli, Alaimus (Eno) (1) menzeli, Crossonema (Tyl) (4) meridionalis, Eudorylaimus (Dor) (1) mesorobustus, Rotylenchus (Tyl) (4) (*) mesostilum, Xiphinema (Dor) (4) (*) micoletzkyi, Achromadora (Chr) (4) micoletzkyi, Dorylaimoides (Dor) (4) microcephalus, Helicotylenchus (Tyl) (3) microdentatus, Paractinolaimus (Dor) (2) microdorus, Merlinius (Tyl) (3) microdorus, Paratylenchus (Paratylenchus) (Tyl) (4)

microphasmis, Neodolichorhynchus (Neodolichorhynchus) (Tyl) (1)

microstilum, Xiphinema (Dor) (4) (*)

millani, Funaria (Dor) (4) (*) minimus, Chiloplacus (Rha) (1) minimus, Plectus (Ple) (4) minimus, Tylencholaimus (Dor) (4) minor, Neopsilenchus (Tyl) (3) minor, Paratrichodorus (Tri) (3) minor, Psilenchus (Tyl) (4) minor, Tylencholaimellus (Dor) (4) (*) minor, Tylolaimophorus (Tri) (3)

minusculus, Paratylenchus (Paratylenchus) (Tyl) (1) minuta, Prodesmodora (Des) (1) minutum, Ogma (Tyl) (1) minutus, Pratylenchus (Tyl) (1) minutus, Pseudhalenchus (Tyl) (1) minutus, Thonus (Dor) (2) minutus, Tylencholaimus (Dor) (4) minutus, Tylenchus (Tyl) (2) minzi, Helicotylenchus (Tyl) (3) mirabilis, Tylencholaimus (Dor) (4) mirus, Paratylenchus (Gracilacus) (Tyl) (1) misellus, Filenchus (Tyl) (4) miser, Microdorylaimus (Dor) (1) modestus, Microdorylaimus (Dor) (3) monegrensis, Paralongidorus (Dor) (4) (*) monohystera, Ecumenicus (Dor) (3) monohystera, Pungentus (Dor) (1) monohystera, Trischistoma (Tri) (4) montanus, Tylencholaimellus (Dor) (4) montenegricus, Dorylaimellus (Dor) (1) monticolus, Dorylaimellus (Dor) (1) montserrati, Criconemoides (Tyl) spec. inquir. (1)

morgensis, (Criconemoides (Criconemoides) (Tyl) (1)

mucronatus, Bursaphelenchus (Aph) (4) mucronatus, Eucephalobus (Rha) (1) multicinctus, Helicotylenchus (Tyl) (3) multigyrus, Coslenchus (Tyl) (4) multipapillatum, Bunonema (Rha) (4) multipapillatus, Ethmolaimus (Chr) (4) multipapillatus, Meylis (Dor) (4) multisetosa, Eumonhystera (Moy) (1) multisquamatum, Crossonema (Tyl) (4) murithi, Longidorella (Dor) (1) murrayi, Ogma (Tyl) (3) muscorum, Prionchulus (Mon) (4) mutabile, Criconema (Nothocriconemella) (Tyl) (4) myceliophagus, Ditylenchus (Tyl) (3) myceliophtorus, Paraphelenchus (Aph) (3)

$\mathbf{N}$

nanellus, Malenchus (Malenchus) (Tyl) (1) nanus, Acrobeloides (Rha) (4)

nanus, Merlinius (Tyl) (3)

nanus, Paratylenchus (Paratylenchus) (Tyl) (4) nanus, Tylencholaimus (Dor) (4)

navarrensis, Domorganus (Ple) (4) (*) nectolineatus, Amplimerlinius (Tyl) (4) (*) neftasiensis, Cervidellus (Rha) (4) neglectus, Pratylenchus (Tyl) (4) neoamblycephalus, Paratylenchus (Paratylenchus) (Tyl) (1)

neoaxeste, Criconema (Criconema) (Tyl) (1) neocapitatus, Dorylaimellus (Dor) (4) neosulcus, Malenchus (Malenchus) (Tyl) (1) neovuittenezi, Xiphinema (Dor) (3) nevadensis, Mesodorylaimus (Dor) (4) (*) nevadensis, Pratylenchoides (Tyl) (4) (*) nevesi, Longidorus (Dor) (4) (*) nigeriense, Xiphinema (Dor) (1) nigra, Prodesmodora (Des) (4) (*) nitidus, Thonus (Dor) (2) nortoni, Ditylenchus (Tyl) (1) nothus, Merlinius (Tyl) (3) nothus, Takamangai (Dor) (1) nudicapitatus, Diplogasteritus (Rha) (1)

obesus, Diphtherophora (Tri) (1) obscurus, Nagelus (Tyl) (3) obtusa, Funaria (Dor) (1) obtusicaudatus, Aporcelaimellus (Dor) (4) obtusus, Nygolaimus (Dor) (1) occidentalis, Oriverutus (Dor) (4) (*) octopapillata, Bastiania (Ple) (1) olearum, Carcharodiscus (Dor) (4) (*) onoensis, Macroposthonia (Tyl) (1) opisthocirculus, Plectus (Ple) (4) opistohysterum, Xiphinema (Dor) (4) orbus, Filenchus (Tyl) (1) ornata, Macroposthonia (Tyl) (4) ornativulvatus, Mesodorylaimus (Dor) (4) (*) ornatus, Dorylaimoides (Dor) (4) orthus, Adenolaimus (Dor) (4) oryzae, Hirschmanniella (Tyl) (1) otophorum, Wilsonema (Ple) (4) ovalis, Malenchus (Neomalenchus) (Tyl) (4) oxura, Seinura (Aph) (3) oxycephaloides, Oxydirus (Dor) (1) oxycephalus, Aulolaimus (Ple) (3) oxycephalus, Oxydirus (Dor) (4) oxycerca, Poikilolaimus (Rha) (1) oxyuroides, Eucephalobus (Rha) (4)

pachtaicum, Xiphinema (Dor) (4) pachycephalus, Malenchus (Neomalenchus) (Tyl) (4) pachydermum, Xiphinema (Dor) (4) (*) pachydermus, Paratrichodorus (Tri) (3) pallida, Globodera (Tyl) (3) palmatum, Ogma (Croserinema) (Tyl) (4) paludicota, Monhystera (Moy) (2) palustris, Plectus (Ple) (4) palustris, Teratocephalus (Rha) (2) papillatus, Clarkus (Mon) (4) papillosa, Phasmarhabditis (Rha) (2) parabrachyuris, Nygolaimus (Dor) (3) paracinctus, Tylencholaimellus (Dor) (4) (*) paraconfusus, Dorylaimoides (Dor) (4) (*) paracornutus, Eucephalobus (Rha) (2) parafuscus, Chitwoodiellus (Dor) (4) (*) parageminus, Iotonchus (Mon) (4) (*) paraglobigerus, Amplimerlinius (Tyl) (4) (*) paragranuliferus, Allodorylaimus (Dor) (4) $\left(^{*}\right)$ paraplatyurus, Helicotylenchus (Tyl) (4) (*) parasimilis, Monhystera (Moy) (1) parasiticus, Dorylaimus (Dor) (4) (*) paratenuis, Nygolaimus (Dor) (1) paravalvulatum, Axonchium (Dor) (4) (*) parietinus, Aphelenchoides (Aph) (4) parietinus, Plectus (Ple) (4) parva, Longidorella (Dor) (3) parvulus, Dorylaimellus (Dor) (4) parvus, Alaimus (Eno) (3) parvus, Bitylenchus (Tyl) (1) parvus, Cephalobus (Rha) (1) parvus, Coomansus (Mon) (4) parvus, Criconemoides (Criconemella) (Tyl) (4) parvus, Microdorylaimus (Dor) (2) parvus, Plectus (Ple) (4) patiens, Eumonhystera (Moy) (4) (*) paucipapillata, Bursilla (Rha) (1) paucipapillatus, Proleptonchus (Dor) (2) pedunculatum, Paraplectonema (Ple) (4) pellio, Pellioditis (Rha) (1) pellioides, Pellioditis (Rha) (1) pellucidus, Semitobrilus (Tri) (4) penardi, Bunonema (Rha) (1) penardi, Laimaphelenchus (Aph) (2) penetrans, Pratylenchus (Tyl) (4) peraticus, Paratylenchus (Gracilacus) (Tyl) (4) perplexans, Diphtherophora (Tri) (1) perscitus, Aorolaimus (Tyl) (4) persegnis, Cephalobus (Rha) (3) peruensis, Macroposthonia (Tyl) (1) pestis, Cacopaurus (Tyl) (4) pinasteri, Bursaphelenchus (Aph) (4) pinguicaudatus, Pratylenchus (Tyl) (3) pini, Longidorus (Dor) (4) (*) pinophilus, Bursaphelenchus (Aph) (1) platycephalus, Malenchus (Malenchus (Tyl) (1) polonicus, Tylencholaimellus (Dor) (4) polyhypnus, Filenchus (Tyl) (1) pombalense, Xiphinema (Dor) (4) (*) popus, Dorylaimus (Dor) (4) potus, Mesodorylaimus (Dor) (1) pratensis, Ethmolaimus (Chr) (4) pratensis, Pratylenchus (Tyl) (4) pratensis, Sauertylenchus (Tyl) (4) (*) pravamphidia, Basiria (Tyl) (3) primitivus, Alaimus (Eno) (4) primitivus, Prismatolaimus (Tri) (4) primitivus, Trichodorus (Tri) (4) princeps, Criconema (Criconema) (Tyl) (4) procerus, Carcharodiscus (Dor) (4) $(*)$ producta, Rhabditis (Rha) (2) productus, Thonus (Dor) (1) profundorum, Longidorus (Dor) (4) projectus, Paratylenchus (Paratylenchus) (Tyl) (3) prolificus, Laimydorus (Dor) (2) propinquus, Chiloplacus (Rha) (2) proximus, Alaimus (Eno) (1) proximus, Tylencholaimus (Dor) (4) 
psammophilus, Paracrobeles (Rha) (4) (*) pseudattentus, Aphanolaimus (Ple) (1) pseudoagilis, Epidorylaimus (Dor) (1) pseudobastiani, Mesodorylaimus (Dor) (1) pseudobrachyurus, Hemicriconemoides (Tyl)

pseudobulbosa, Eumonhystera (Moy) (4) pseudocoxi, Xiphinema (Dor) (4) pseudoelongata, Rhabditella (Rha) (1) pseudolatus, Pseudacrobeles (Bunobus) (Rha) (4) $(*)$

pseudomicoletzkyi, Achromadora (Chr) (3) pseudoparietinus, Paraphelenchus (Aph) (4) pseudorecurvus, Mesodorylaimus (Dor) (4) (*) pseudorobustus, Helicotylenchus (Tyl) (4) pseudosolivaga, Macroposthonia (Tyl) (4) pseudostagnalis, Laimydorus (Dor) (4) pseudosubtilis, Mesodorylaimus (Dor) (1) pulchrum, Labronema (Dor) (1) pumila, Takamangai (Dor) (1) pumilus, Rotylenchus (Tyl) (3) punctata, Pelodera (Rha) (3) punctata, Punctodera (Tyl) (4) punctata, Zeldia (Rha) (4) punctatus, Prionchulus (Mon) (3) pygmaea, Stegelletina (Rha) (4) (*) pyrenaicum, Xiphinema (Dor) (4)

quadrifer, Scutylenchus (Tyl) (4) quartus, Filenchus (Tyl) (4)

radicicola, Subanguina (Tyl) (1) radicicola, Xiphinema (Dor) (1) rapax, Labronema (Dor) (1) rapsus, Microdorylaimus (Dor) (1) raskiensis, Macroposthonia (Tyl) (3) raskii, Tylencholaimellus (Dor) (4) ratzeburgensis, Punctodora (Chr) (2) reisi, Longidorus (Dor) (4) (*) reniformis, Rotylenchulus (Tyl) (4) reticulatum, Bunonema (Rha) (2) rhizophilus, Plectus (Ple) (4) rhombosquamatum, Ogma (Ogma) (Tyl) (4) rhombus, Coslenchus (Tyl) (4) rhopalocercus, Uliginotylenchus (Tyl) (3) richtersi, Bunonema (Rha) (4) rigidus, Panagrolaimus (Rha) (4) risoceiae, Iotonchus (Mon) (3) ritteri, Pratylenchoides (Tyl) (3) rivalis, Diplogaster (Rha) (4) rivesi, Xiphinema (Dor) (4) robustus, Rotylenchus (Tyl) (4) rohtangus, Helicotylenchus (Tyl) (1) rosmarini, Criconemoides (Criconemella)

(Tyl) (4) (*)

rostochiensis, Globodera (Tyl) (4) rotundicauda, Helicotylenchus (Tyl) (3) rotundicauda, Macroposthonia (Tyl) (4) rotundicaudatus, Iotonchus (Mon) (4) (*) rotundicephalus, Dorylaimoides (Dor) (4) (*) ruffoi, Mononchoides (Rha) (1) rugatocuticulatus, Rotylenchus (Tyl) (1) rugosus, Coslenchus (Tyl) (1) rugosus, Eudorylaimus (Dor) (3) rugosus, Scutylenchus (Tyl) (3) ruricola, Achromadora (Chr) (4) rustica, Macroposthonia (Tyl) (4) sabinae, Plectus (Ple) (4) (*) sacchari, Aphelenchoides (Aph) (1) sahelense, Xiphinema (Dor) (4) salinaria, Stegelletina (Rha) (4) (*) sambesii, Plectus (Ple) (4) sandneri, Filenchus (Tyl) (4) santos, Xiphinema (Dor) (4) (*) saprophilus, Aphelenchoides (Aph) (1)

saxifragae, Enchodelus (Enchodelus) (Dor) (1) schachtii, Heterodera (Tyl) (4) schneideri, Rhabditophanes (Rha) (4) schulzi, Enoplus (Eno) (4) sculptus, Trophurus (Tyl) (3) seguranus, Nygolaimus (Dor) (4) (*) seinhorsti, Hoplolaimus (Basirolaimus) (Tyl) (1) semipenetrans, Tylenchulus (Tyl) (3) serpentinus, Laimydorus (Dor) (2) serranus, Bitylenchus (Tyl) (4) (*) sessus, Mylonchulus (Mon) (3) setariae, Xiphinema (Dor) (1) setifera, Tripyla (Tri) (4) setosus, Acrobeloides (Rha) (4) setosus, Epitobrilus (Tri) (1) sexdentati, Bursaphelenchus (Aph) (4) shamimi, Proleptonchus (Dor) (4) sheri, Paratylenchus (Paratylenchus) (Tyl) (4) sheri, Tripylina (Tri) (3)

siddiqii, Amplimerlinius (Tyl) (4)

sigmaturus, Mylonchulus (Mon) (4) silvaticus, Eudorylaimus (Dor) (1) silvesi, Xiphinema (Dor) (4) (*) silvester, Aphelenchoides (Aph) (1) silvestris, Pungentus (Dor) (4) similis, Eumonhystera (Moy) (4) similis, Macroposthonia (Tyl) (3) similis, Nygolaimus (Dor) (4) (*) similis, Paratylenchus (Paratylenchus) (Tyl) (4) similis, Stegelletina (Rha) (4) similis, Trichodorus (Tri) (3) simmenensis, Coomansus (Mon) (2) simplex, Eumonhystera (Moy) (1) singulus, Acrobeles (Rha) (1) skrjavini, Acromoldavicus (Rha) (4) solivaga, Macroposthonia (Tyl) (4) sparsus, Trichodorus (Tri) (3) spengelii, Mesodorylaimus (Dor) (1) sphaerocephalus, Macroposthonia (Tyl) (4) spiculigera, Mesorhabditis (Rha) (4) stagnalis, Dorylaimus (Dor) (4) stagnalis, Monhystera (Moy) (4) stecki, Tylencholaimus (Dor) (4) stefanskii, Amphidelus (Eno) (1) stefanskii, Brevitobrilus (Tri) (4) steineri, Paratylenchus (Gracilacus) (Tyl) (4) stigmatus, Rhabditidoides (Rha) (1) straeleni, Paratylenchus (Gracilacus) (Tyl) (4) striatus, Dorylaimoides (Dor) (4) (*) striatus, Eucephalobus (Rha) (3) striatus, Paratrophurus (Tyl) (4) (*) striatus, Psilenchus (Tyl) (4) striatus, Tylencholaimellus (Dor) (4) striatus, Tylenchorhynchus (Tyl) (3) strongyloides, Pelodera (Rha) (1) studeri, Miconchus (Mon) (4) subdigitalis, Eudorylaimus (Dor) (1) sublabiatus, Metaporcelaimus (Dor) (1) subsimilis, Mylonchulus (Mon) (3) subtenuis, Aphelenchoides (Aph) (1) subterraneus, Mylonchulus (Mon) (1) subtilis, Mesodorylaimus (Dor) (1) sulcatus, Neodolichorhynchus (Neodolichorhynchus) (Tyl) (4)

superbus, Aporcelaimus (Dor) (2) superbus, Mononchus (Mon) (4) sylphoides, Opisthodorylaimus (Dor) (4) symmetricus, Chiloplacus (Rha) (1) sympathicus, Anatonchus (Mon) (4)

tabacum, Globodera (Tyl) (3)

tabacum, Pseudacrobeles (Pseudacrobeles) (Rha) (1)

tarjani, Belondira (Dor) (4)

tartuensis, Scutylenchus (Tyl) (3)

tenax, Achromadora (Chr) (2)

tenellus, Mesodorylaimus (Dor) (2)

tenuicaudatus, Ironus (Eno) (4)

tenuicaudatus, Laimydorus (Dor) (1)

tenuicaudatus, Paratylenchus (Paratylenchus)

(Tyl) (1)

tenuicaudatus, Udonchus (Ple) (4)

tenuis, Chiloplacus (Rha) (4)

tenuis, Discolaimoides (Dor) (1)

tenuis, Nygolaimus (Dor) (1)

tenuis, Plectus (Ple) (2)

tenuis, Tenunemellus (Tyl) (1)

tenuis, Tripyla (Tri) (1)

teratospicularis, Bursaphelenchus (Aph) (4)

teres, Alaimus (Eno) (1)

teres, Dorylaimoides (Dor) (4)

teres, Paratrichodorus (Tri) (4)

teres, Paratylenchus (Gracilacus) (Tyl) (4)

teres, Paravulvus (Dor) (1)

teres, Pelodera (Rha) (1)

teres, Pseudacrobeles (Pseudacrobeles) (Rha)

(2)

teres, Tylencholaimus (Dor) (4)

terextremus, Psilenchus (Tyl) (1)

terrestris, Rhabdolaimus (Ple) (4)

terrestris, Teratocephalus (Rha) (4)

terrestris, Tylencholaimus (Dor) (4) (*)

terricola, Achromadora (Chr) (4)

terrícola, Prodesmodora (Des) (3)

terricola, Rhabditis (Rha) (4)

texanus, Discolaimus (Dor) (4)

thamesi, Meloidogyne (Tyl) (1)

thienemanni, Loofia (Tyl) (3)

thornei, Enchodelus (Paraenchodelus) (Dor) (1)

thornei, Filenchus (Tyl) (4)

thornei, Helicotylenchus (Tyl) (1)

thornei, Hemicycliophora (Tyl) (3)

thornei, Microdorylaimus (Dor) (4)

thornei, Pratylenchus (Tyl) (4)

thylactus, Boleodorus (Tyl) (4)

thymophilus, Allodorylaimus (Dor) (4) (*)

tigrodon, Panagrolaimus (Rha) (1)

tridentatus, Anatonchus (Mon) (4)

trifolii, Heterodera (Tyl) (4)

triformis, Ditylenchus (Tyl) (1)

trilineatus, Chiloplacus (Rha) (4)

tripartitum, Cruznema (Rha) (3)

tristis, Protorhabditis (Rha) (1)

tritici, Anguina (Tyl) (3)

troglodytes, Stenonchulus (Tri) (3)

troglophilus, Cephalobus (Rha) (1)

truncatus, Malenchus (Malenchus) (Tyl) (1)

truncatus, Mononchus (Mon) (4) 
truncatus, Plesiorotylenchus (Tyl) (1) tuerkorum, Bunonema (Rha) (4) tumida, Basiria (Tyl) (1)

tunbridgensis, Mononchus (Mon) (4) tunisiensis, Helicotylenchus (Tyl) (4) turcicum, Xiphinema (Dor) (3)

turkeyensis, Coslenchus (Tyl) (4)

tusciae, Bursaphelenchus (Aph) (4) typica, Chronogaster (Ple) (4)

uliginosus, Prodorylaimus (Dor) (4) unedoi, Longidorus (Dor) (4) (*)

unguicolis, Pseudacrobeles (Pseudacrobeles)

$$
\text { (Rha) (4) (*) }
$$

uniformis, Paramphidelus (Eno) (1) unisexus, Rotylenchus (Tyl) (3)

\section{V}

vadensis, Macroposthonia (Tyl) (4)

vandenbrandei, Paratylenchus (Paratylenchus) (Tyl) (4) variabilis, Pseudacrobeles (Pseudacrobeles)

(Rha) (4)

variacaudatum, Labronema (Dor) (1) varicaudatus, Helicotylenchus (Tyl) (3) ventrosignatus, Bitylenchus (Tyl) (4) (*) verrucosus, Prismatolaimus (Tri) (1)

veruculatus, Paratylenchus (Paratylenchus)

$$
\text { (Tyl) (1) }
$$

vexilliger, Cervidellus (Rha) (4)

vicinus, Irantylenchus (Tyl) (3)

villosa, Geomonhystera (Moy) (4)

vineacola, Longidorus (Dor) (4)

vinearum, Longidorus (Dor) (4) (*)

virginianus, Dorylaimellus (Dor) (3)

virgo, Labronema (Dor) (1)

virtudesae, Ditylenchus (Tyl) (4) (*)

viruliferus, Trichodorus (Tri) (3)

viviparus, Hexatylus (Tyl) (1)

vuittenezi, Xiphinema (Dor) (4)

vulgaris, Bitylenchus (Tyl) (3)

vulgaris, Eumonhystera (Moy) (4)

vulgaris, Helicotylenchus (Tyl) (4) vulgaris, Solididens (Dor) (1)

vulnus, Pratylenchus (Tyl) (4)

vulvapapillatum, Labronema (Dor) (4)

\section{W}

wangi, Monhystera (Moy) (1)

$\mathbf{X}$

xenoplax, Macroposthonia (Tyl) (4)

xylophilus, Bursaphelenchus (Aph) (4)

zeae, Heterodera (Tyl) (4)

zeae, Pratylenchlus (Tyl) (3)

zeae, Tylenchorhynchus (Tyl) (1)

zeelandicum, Doryllium (Dor) (4)

zelli, Prionchulus (Mon) (1)

zernovi, Ogma (Ogma) (Tyl) (4)

zschokkei, Coomansus (Mon) (4)

zujarensis, Chronogaster (Ple) (4) (*)

zullinii, Prodesmodora (Des) (4) (*) 